\title{
Rotational basement kinematics deduced from remagnetized cover rocks (Internal Sierras, southwestern Pyrenees)
}

\author{
Belén Oliva-Urcia ${ }^{1,2}$ and Emilio L. Pueyo ${ }^{3,4}$ \\ Received 2 February 2006; revised 27 September 2006; accepted 16 March 2007; published 17 August 2007.
}

[1] Paleomagnetic data from the Internal Sierras unravel the kinematic relationship between basement (Guarga, Gavarnie, Bielsa) and cover thrusts (LarraMonte Perdido). The new data come from an area of $100 \mathrm{~km}$ along strike and $5-15 \mathrm{~km}$ across strike of the southwestern Pyrenees. The area covers a variety of structural positions that range from cover to basement thrusts. From 84 sites located in Upper Cretaceous, two meaningful magnetic components are found: (1) the higher-temperature $\mathrm{C}$ component (unblocks at $575^{\circ} \mathrm{C}$ ) presents two polarities, is prefolding, has a mean declination and inclination (D/I) of 010/44 $\left(\alpha_{95}=8, \mathrm{k}=15\right)$, and is considered primary; and (2) the intermediate B component (unblocks between $250^{\circ} \mathrm{C}$ and $\left.450^{\circ} \mathrm{C}\right)$ has a mean $\mathrm{D} / \mathrm{I}$ of $198 /-43\left(\alpha_{95}=\right.$ $4, \mathrm{k}=18$ ) and has always reverse polarity and postfolding. The nine sites located in the Eocene flysch, south of the Upper Cretaceous, show the same postfolding component (B). The acquisition of this intermediate component alludes to a widespread, tectonic-related remagnetization event affecting the Internal Sierras. This event must be younger than the folding of the flysch deposits (middle-upper Eocene). The tilting induced by the basement thrust (Gavarnie, Bielsa) in the axial zone does not alter the inclination of the B, so that the sediments acquire the $\mathrm{B}$ component later than Priabonian (emplacement age of the Gavarnie thrust). The B component is rotated clockwise with respect to the Tertiary reference. This means that the rotation takes place after the remagnetization event. The position of the $\mathrm{C}$ component before the rotation of the $\mathrm{B}$ component is negligibly rotated $\left(\mathrm{D} / \mathrm{I}\right.$ of $\left.002 / 44 ; \alpha_{95}=7, \mathrm{k}=94\right)$ with respect to the Cretaceous reference; therefore the $\mathrm{B}$ component records the last and only rotational event in the region. The rotation is related to the latest

\footnotetext{
${ }^{1}$ Department of Geological Sciences, University of Michigan, Ann Arbor, Michigan, USA.

${ }^{2}$ Now at Departamento de Geodinámica Interna, Universidad de Zaragoza, Zaragoza, Spain.

${ }^{3}$ Departamento de Geodinámica Interna, Universidad de Zaragoza, Zaragoza, Spain.

${ }^{4}$ Now at Unidad de Geología y Geofísica, Instituto Geológico y Minero de España, Zaragoza, Spain.

Copyright 2007 by the American Geophysical Union. 0278-7407/07/2006TC001955
}

basement deformation (Guarga thrust) during upper Oligocene times, and it reflects the regional shortening gradient in the southwestern Pyrenees. The emplacement of the Larra-Monte Perdido cover thrust system that took place prior to basement thrusts mentioned above did not undergo any significant rotation. Citation: Oliva-Urcia, B., and E. L. Pueyo (2007), Rotational basement kinematics deduced from remagnetized cover rocks (Internal Sierras, southwestern Pyrenees), Tectonics, 26, TC4014, doi:10.1029/2006TC001955.

\section{Introduction}

[2] To understand the construction of continental collision orogens in compression tectonic regimes, it is essential to know how the orogenic wedge develops not only in terms of the sequence of thrusts but also taking into account the vertical axis rotations (VARs). The timing and magnitude of displacement of thrusts together with the timing and magnitude of VARs will constrain the tectonic evolution of the orogen. Understanding the interactions between cover and basement thrust systems that are separated by detachment levels is a difficult task, especially in orogens where the deeper portions are not well exposed or the upper portions have been eroded. Classic structural techniques (mapping, cross section balancing, cleavage analysis, etc.) alone do not sufficiently unravel the age and magnitude of deformation sequences and the coupling between cover and basement systems. However, when such techniques are integrated with paleomagnetic analysis, which at this time is the only reliable way to characterize VARs, many parameters such as along strike shortening gradient, are possible to identify. This integration of data allows reliable restoration of finite deformation to a predeformational stage. In particular, the shortening gradient obtained from balanced cross sections is key to understanding three-dimensional deformation patterns (including mechanisms of lateral transference) in an orogen. Besides the determination of VARs, to establish the time of acquisition of different magnetic components allows distinguishing different episodes during the rising history of an orogen. Secondary components provide valuable information, especially when remagnetization processes have partially overprinted the original magnetization since they represent snapshots of the deformation history of the orogen.

[3] The Pyrenean orogen has been the subject of systematic paleomagnetic studies for the last three decades in both basement blocks and cover systems. The salient that conforms the South Pyrenean Central Unit (SPCU, sector A in Figure 1a), shows no significant rotations in its frontal 


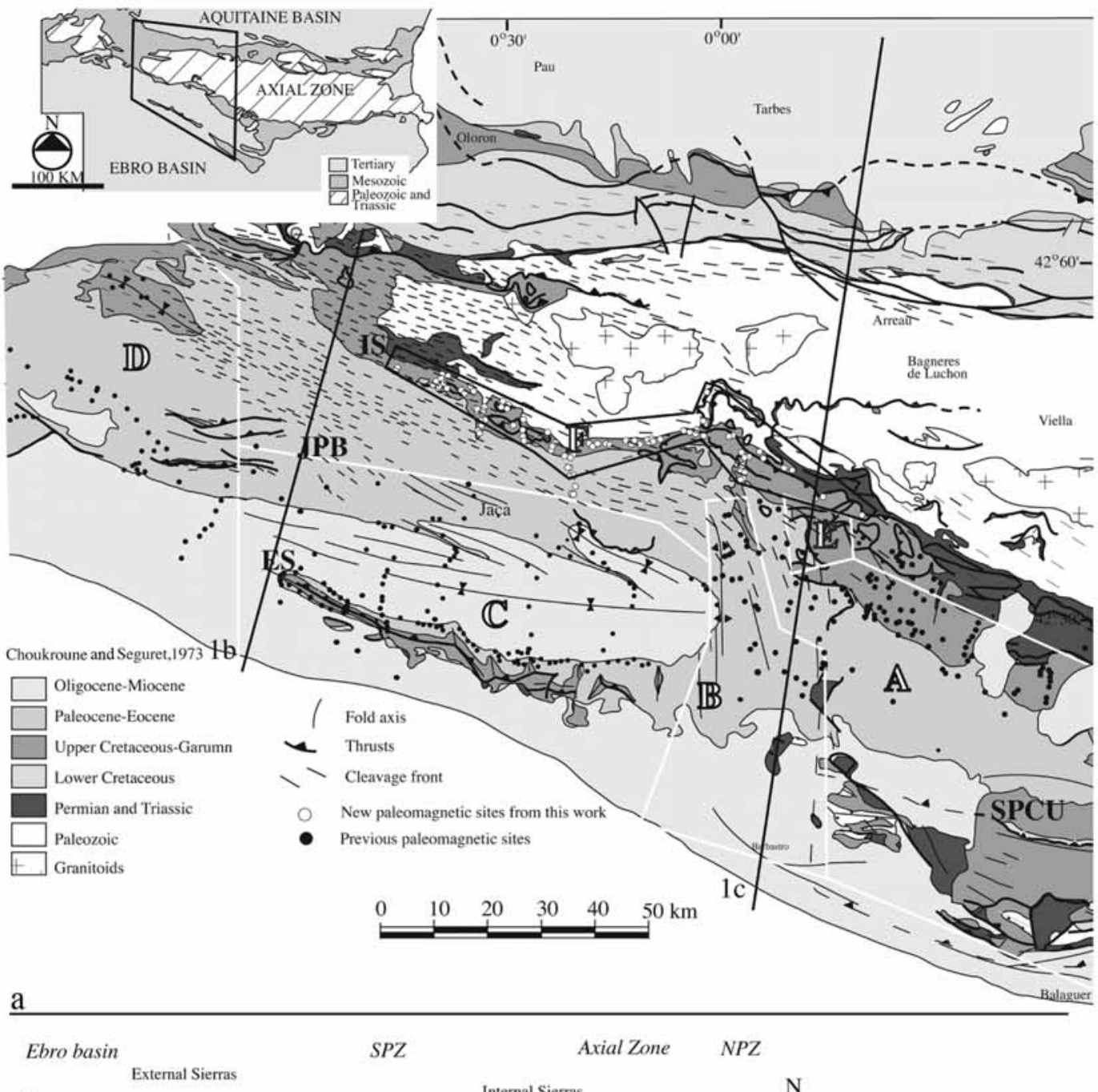

$1 \mathrm{~b}$

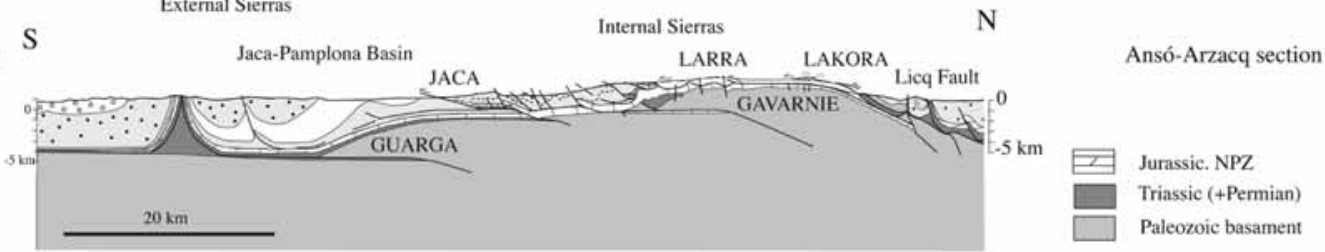

$\therefore$ Upper Oligocene-Miocene (molasse), SPZ $\square$ Middle-Upper Eocene (marine molasse). $\mathrm{b}$

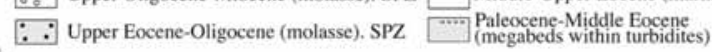

b: conglomerates (Aptian-Upper Cret.)

Ebro basin

SPCU

-. Lower Cretaceous (carbonates). NPZ

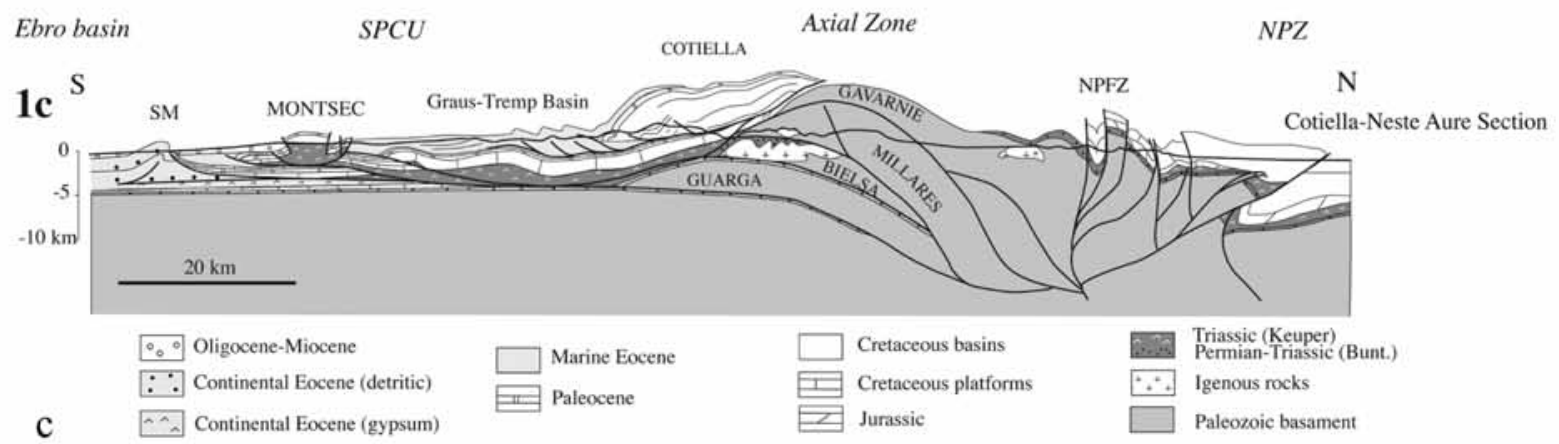

Figure 1 
portions [Dinarès, 1992; Dinarès et al., 1992; Pascual, 1992; Meigs et al., 1996; Meigs and Burbank, 1997; Beamud et al., 2003, 2004], but remarkable rotations are found in oblique structures: counterclockwise rotations in the eastern side of the SPCU and higher magnitudes of clockwise rotations (up to $80^{\circ}$ ) in the western side of the SPCU (sector B in Figure 1a) related to distributed shortening [Keller et al., 1994; Dinarès-Turell and García-Senz, 2000; Sussman et al., 2004; Dinarès, 1992; Muñoz et al., 2003; Fernández et al., 2003; Fernández, 2004]. West of the SPCU, a variable degree of clockwise rotation $\left(50^{\circ}-25^{\circ}\right.$ [Hogan and Burbank, 1996; Pueyo et al., 2002, 2003a, $2003 \mathrm{~b}, 2004])$ is associated with the imbrication of the basal thrust system, which gave rise to the External Sierras (ES) and the piggyback movement of the Jaca-Pamplona basin (sector $\mathrm{C}$ in Figure 1a). These rotations are, somehow, expectable if we take into account the differences of orogenic shortening detected by cross section balancing between the SPCU and the western portion of the External Sierras [Martínez-Peña and Casas-Sainz, 2003; Teixell, 1996, 1998]. In contrast, no rotation has been determined in the western sector of the Jaca-Pamplona Basin (sector D in Figure 1a) [Larrasoaña et al., 2003a; Almar et al., 2004]. Most of this large data set shows well-proved primary directions; however, a prefolding remagnetization component has been found in specific areas as in the Organyà basin [Dinarès-Turell and García-Senz, 2000; Gong et al. 2005] (Figure 1a, northwest corner of A sector) and in the Cotiella massif [Garcés et al., 2003, 2005] in the Upper Cretaceous limestones in relation to diagenetic processes (E sector in Figure 1a). Synfolding and prefolding remagnetizations have been described in the Permian-Triassic materials [Van der Voo and Boessenkol, 1973; Schott and Peres, 1988; Bates, 1989; McClelland and McCaig, 1989; Larrasoaña et al., 2003b].

[4] The ES are the southernmost expression of the movement of the South Pyrenean Sole Thrust (Guarga thrust). In the ES local rotations have been documented in relation to the emplacement of the Guarga basement thrust and its progressive transfer of shortening to the west [Hogan, 1993; Millán, 1996; Pueyo, 2000]. The Internal Sierras (IS) are situated around $50 \mathrm{~km}$ to the north of the ES. The IS are in the southwestern Pyrenees between the axial zone to the north and the Jaca-Pamplona turbidic basin to the south. The rocks that outcrop in the IS are MesozoicTertiary sediments (F sector in Figure 1a). These materials are affected by both the older, uppermost cover thrusts (Larra-Monte Perdido system) and the younger, underlying basement thrusts (Gavarnie, Millares, Bielsa and Guarga thrusts). The main goals of this paper are to characterize the rotation pattern in the IS and to unravel the kinematic evolution of coupling between cover and basement thrust systems in the southwestern Pyrenees by means of paleomagnetic analysis. Along with the interplay of the thrusts systems, the shortening evolution and its relation to the deformation of the basement is also addressed.

\section{Geological Setting}

[5] The Pyrenees are an excellent geological example of a double vergent mountain belt because of the relative simplicity of the orogen, the availability of synorogenic materials, the outstanding exposures and the degree of preservation that make possible the acquisition of surface data. In addition, the development and interpretation of deep seismic profiles (ECORS Pyrenees, west Pyrenees, Bay of Biscay and the Estudios Sismicos de la Corteza Iberica Norte's in the Cantabric margin) and their integration with surface data have significantly progressed the understanding of the structural evolution of this mountain belt, first across strike with the balanced cross sections, and second along strike, comparing the shortening transfer looking at the time and evolution of structures within the different cross sections [e.g., ECORS Pyrenees Team, 1988; Choukroune, 1992; Muñoz, 1992; Teixell, 1998; Fitzgerald et al., 1999; Beaumont et al., 2000; Vacher and Soriau, 2001; Vergés and García-Senz, 2001; Vergés et al., 2002; Martínez-Peña and Casas-Sainz, 2003].

[6] In the southwestern part of this Mountain Range, the Internal Sierras represent a fairly linear topographic feature of abrupt terrain, with elevation differences of more than $1700 \mathrm{~m}$ and altitudes up to $3355 \mathrm{~m}$ (Monte Perdido). The rocks that characterize the IS include limestones, marls, calcarenites and turbiditic sediments of Mesozoic-Tertiary age. The position of these sediments varies along strike; that is, in the western side of the studied area, these rocks lie unconformably over the basement, but more to the east, they are detached over Paleozoic or Triassic evaporites further east, in the Bielsa region [Ríos et al., 1982a; 1982b, 1987a, 1987b; Martínez-Peña and Casas-Sainz, 2003] (Figure 1a).

\subsection{Stratigraphy of the IS}

[7] The studied Mesozoic-Tertiary rocks comprise Upper Cretaceous and Eocene sediments. The Upper Cretaceous shows two main depositional sequences. The older sequence

Figure 1. (a) Geological map of the Pyrenees [see Choukroune and Séguret, 1973]. Paleomagnetic sampling areas have been also located. A, South Pyrenean Central Unit (SPCU); B, oblique structures in the western side of the SPCU; C, External Sierras (ES) and Jaca-Pamplona piggyback basin (JPB); D, western area of the Jaca-Pamplona Basin; E, Cotiella Unit; F, Internal Sierras (IS). Lines 1b and 1c are the cross sections below. (b) Ansó-Arzacq section in the western part of the IS from Teixell [1992, 1996] and Teixell and Garcia-Sansegundo [1995], modified in the southern part following an alternative interpretation by Millán [1996]. (c) Cotiella-Neste Aure section from Martínez-Peña and Casas-Sainz [2003]. In the cross sections, the name of the thrusts are indicated by capital letters, the structural zones are indicated by italics. SPZ, South Pyrenean Zone; NPZ, North Pyrenean Zone; NPFZ, North Pyrenean Zone; SPCU, South Pyrenean Central Unit; SM, Serres Marginals. 
is represented by $150 \mathrm{~m}$ of limestones and carbonatic sediments (Calcaires des Cañons) deposited during the $10 \mathrm{Ma}$ transgressive cycle in the Cenomanian [Martin-Chivelet et $a l ., 2002]$. The younger sequence is represented by an average of $600 \mathrm{~m}$ of silicic-carbonate platform sediments (Zuriza and Marboré formations in Campanian-Maastrichtian times) deposited during convergence. The compression dominated during middle Santonian, although is during the Campanian when the marine sediments record the maximum extension [Martín-Chivelet et al., 2002, and references therein]. Scarce paleomagnetic data from other locations of Iberia indicate that the sedimentation in the Upper Cretaceous took place after the rotation with respect to Europe (Cenomanian at latest is when the rotation finished [Juárez et al., 1998]). Paleocene and lower Eocene deposits are represented by carbonatic platform sediments (limestones and dolomites) and marls, which show younger sedimentation age toward the south. The Eocene is represented by the turbidites from the Hecho Group [Mutti et al., 1972] in the Jaca-Pamplona basin. The turbidites are composed by Bouma [1964] cycles (calcarenites and marls of decimeter scale) and up to 13 alternating megabreccia units (as thick as $40 \mathrm{~m}$ ). The turbidites overlie the Paleocene platform deposits, showing about $4.5 \mathrm{~km}$ thickness. The age of the turbidites expands from Ilerdian to Lutetian times [Labaume et al., 1983; Canudo and Molina, 1988; Barnolas and Teixell, 1994; Mutti et al., 2003; Payros et al., 2006]. Paleomagnetic Tertiary references in Iberia do not show any significant difference with respect to European poles neither to the present north magnetic pole.

\subsection{Structural Features in the IS}

[8] The main structural characteristic of the IS is the Larra-Monte Perdido cover thrust system [Souquet, 1967; Séguret, 1972]. This thrust system is characterized by series of subhorizontal detachment horizons. The horizons have displacements between 3 and $5 \mathrm{~km}$ in a southward direction, and they have associated propagation folds [Alonso and Teixell, 1992]. The detachments affect the cover of Upper Cretaceous-Eocene sequence. In the west of the studied area, the imbricate thrust system merges in a floor detachment level which is connected to the Lakora basement thrust to the north of the axial zone [Labaume et al., 1985; Teixell, 1992, 1996]. A foreland breaking sequence of basement thrusts affects this cover thrust system later. The sequence of basement thrusts differs from east to west in the studied area. In the west and from north to south they include the Gavarnie and Guarga thrusts [Labaume et al., 1985; Teixell, 1992, 1996; Teixell and Garcia-Sansegundo, 1995]. In the east the Gavarnie, Millares, Bielsa, and Guarga thrusts build the foreland breaking sequence [Martínez-Peña and Casas-Sainz, 2003; Casas et al., 2003] (Figures 1b and 1c). In general, deformation progresses from east to west [Teixell, 1992, 1996; Millán et al., 2000; Martínez-Peña and Casas-Sainz, 2003, and references therein].

[9] South of the IS, several pulses of deformation have been recorded in the turbiditic basin [Labaume et al., 1985; Barnolas and Teixell, 1994; Payros et al., 1999]. The deformation has been classically grouped in two phases. The first phase (middle-upper Eocene) coincides with the movement of the Larra-Monte Perdido thrust system [Séguret, 1972; Teixell, 1992]. The second one is related to the emplacement of the Gavarnie basement thrust (upper Eocene-lower Oligocene [Labaume et al., 1985; Teixell, 1992; Holl and Anastasio, 1995]). The second phase generated south verging mesoscale folds and a penetrative and widespread cleavage domain [Labaume et al., 1985; Teixell, 1992; Holl and Anastasio, 1995].

[10] The cleavage domain is a fan-shaped planar fabric region with a general E-W trending. The region affected by this planar fabric in the southwestern Pyrenees centers in the axial zone and affects the IS and the northern part of the Jaca-Pamplona turbiditic basin [Choukroune and Séguret, 1973; Choukroune, 1976]. The strain rate in the cleavage domain increases from the southern front in the JacaPamplona turbiditic basin to the north in the axial zone [Choukroune, 1976; Holl and Anastasio, 1995]. The depth of cleavage domain development depends basically on sedimentary and tectonic loads together with temperature and tectonic gradients [Maxwell, 1962; Mattauer, 1976; Price and Cosgrove, 1990]. The mechanism of cleavage development in the studied area is pressure solution [Holl and Anastasio, 1995]. The mineralogy and composition of the rocks control the temperature of the development of pressure solution cleavage. For limestones the temperature is around $170^{\circ} \mathrm{C}$ [Groshong et al., 1984], and for siliciclastic rocks it is $300^{\circ} \mathrm{C}$ [Kerrich and Allison, 1979; Elliot, 1973, 1976]. The temperature of the materials where the cleavage domain develops in the southwestern Pyrenees has been calculated to be around $200^{\circ}-250^{\circ} \mathrm{C}$ from chemical analysis in fluid inclusions in veins [Travé et al., 1997; McCaig et al., 2000]. The overburden on top of these cleaved rocks is calculated to be around 4-7 km [Grant et al., 1990; Travé et al., 1997; Teixell et al., 2000; McCaig et al., 2000]. The impurities present in limestones favor the development of pressure solution cleavage planes [Marshak and Terry, 1985]. We consider the cleavage domain because all sites in this study fall within this region with a distinct planar fabric.

\section{Sampling and Laboratory Procedures}

[11] Using a portable, water-refrigerated drill, we collected samples in 93 paleomagnetic sites. In each site between 10 and 12 standard cores were drilled within 5-20 m of stratigraphic section. At 10 sites with particularly difficult access, oriented blocks were collected. Bedding and cleavage orientation were also recorded.

[12] The sampling sites were concentrated in Upper Cretaceous deposits except for nine sites drilled in the Eocene turbidites deposits (eight of them in four metricscale folds). The sites are distributed along the strike of the IS extending $100 \mathrm{~km}$ in length and 5 to $15 \mathrm{~km}$ in width in map view (Figure 1a, sector F). The sites are located in different thrusts sheets with diverse bedding attitudes. The majority of sites in the Upper Cretaceous rocks could not be sampled in outcrop-scale folds as in the flysch deposits. 

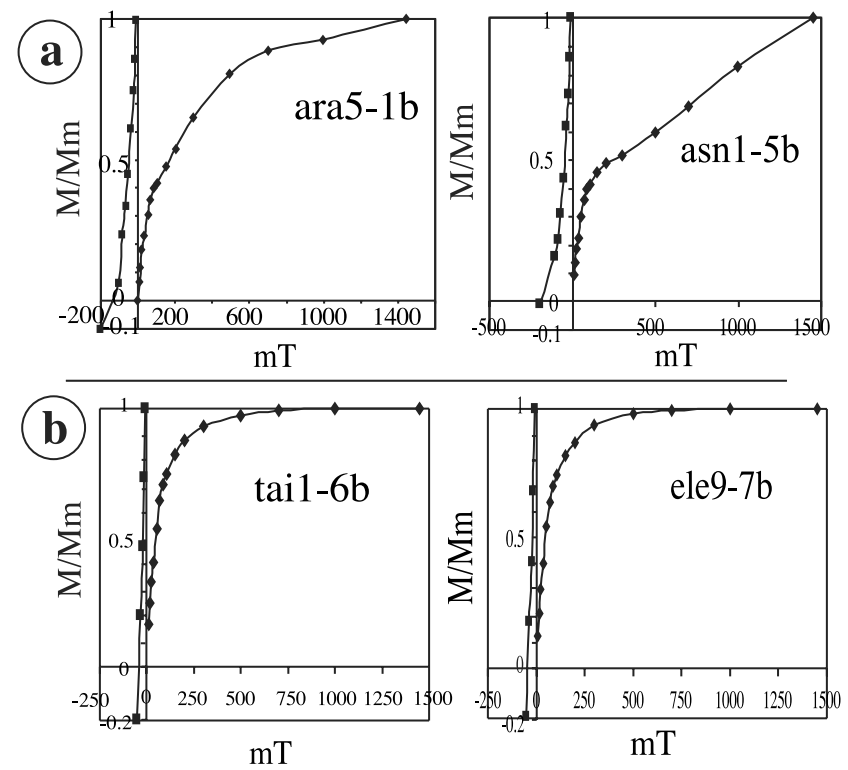

Figure 2. (right) IRM acquisition curves and (left) backfield experiments. (a) Representative curves of the Calcaires des Cañons (type 1, see text for details) where saturation is not reached, indicating the presence of a "hard" ferromagnetic mineral (goethite, hematite). (b) Representative curves of the top of the Upper Cretaceous (tai1-6b) and Eocene rocks (ele9-7b) (type 2). Saturation is reached around $200 \mathrm{mT}$ indicating the presence of a "soft" coercivity mineral (magnetite probably). $Y$ axis, normalized remanent magnetization; $X$ axis, applied field (in $\mathrm{mT}$ ).

However bedding attitude differences allow the fold test application. Structural observations confirm the absence of plunging structures.

[13] Magnetic mineralogy experiments have been carried out in order to characterize the magnetic carriers, in terms of nature and grain size, within the sedimentary rocks of the Internal Sierras. The rock magnetism analyses comprise (1) acquisition curves of isothermal remanent magnetization (IRM) [Dunlop, 1972] where the maximum applied field is $1.45 \mathrm{~T}$, and (2) stepwise thermal demagnetization of composite IRM, where three different magnetic fields (hard 1.45; medium 0.4 , and soft $0.12 \mathrm{~T}$ ) are applied in three different and perpendicular axis prior to thermal demagnetization of the sample [Lowrie, 1990]. Both types of experiments were performed in the Gams Paleomagnetic Laboratory (Leoben University, Austria) using a Walker electromagnet $(1.45 \mathrm{~T})$ and a $2-\mathrm{G}$ pulse magnetizer $(2.5 \mathrm{~T})$ on standard specimens. Low temperature experiments and hysteresis loops were conducted at the Institute for Rock Magnetism (University of Minnesota) using a Magnetic Properties Measurement System (MPMS) magnetometer (Quantum Design Ltd.) for low-temperature experiments, and a Micro VS Magnetometer (Princeton Instrument Corporation) on powder chips of $250-300 \mathrm{mg}$ and a Vibrating Sample Magnetometer (Princeton Instrument Corp.) on standard specimens for hysteresis loops.
[14] Demagnetization procedures were performed at the Gams Paleomagnetic Laboratory and at the Institut de Ciencies de la Terra "Jaume Almera" CSIC-Universitat de Barcelona, Spain. Magnetization measurements during stepwise thermal demagnetization (every $50^{\circ}$ to $25^{\circ} \mathrm{C}$ at MMTD and Schonsted TSD-1 ovens) were obtained with a 2-G and GM-400 cryogenic magnetometers. Susceptibility was monitored during the demagnetization in both laboratories to control the evolution of magnetic mineralogy.

[15] Characteristic remanent magnetization (ChRM) directions for each sample was computed using the principal component analysis (PCA) routine [Kirschvink, 1980] provided by the Paldir software package (Utrecht Paleomagnetic Laboratory). Alternative calculations on site level include using demagnetization circles [Bailey and Halls, 1978] and the stacking routine [Scheepers and Zijderveld, 1992; Pueyo et al., 2007]. Site means were obtained using Fisher [1953] statistics by means of the Stereonet 6.0 and 61.3.3 software (R. Allmendinger, Software: Stereonet 6.0, academic version, 1995). Fold tests were conducting using the IAPD-32 program (T. Torsvik et al., Software IAPD-32,
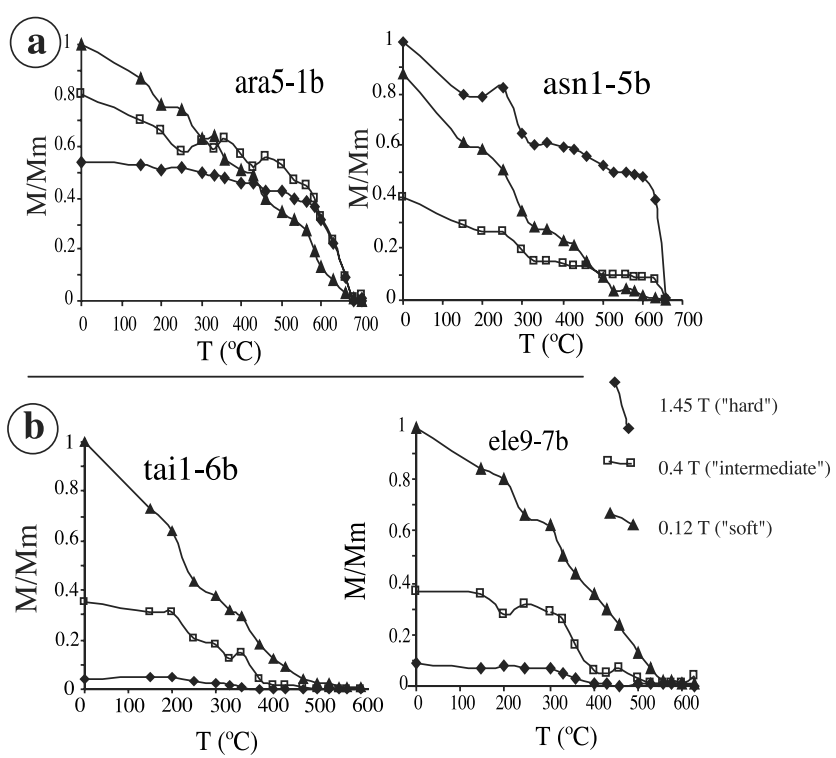

Figure 3. Intensity decay of the stepwise thermal demagnetization of composite IRM: application of $1.45 \mathrm{~T}$, $0.4 \mathrm{~T}$, and $0.12 \mathrm{~T}$ in three different orthogonal axis following by thermal demagnetization [Lowrie, 1990]. The intensity decay in each axis is measured and represented separately. (a) Representative curves of the lower part of Upper Cretaceous with a "hard" ferromagnetic mineral (hematite, from the temperature decay) and a "medium" coercivity mineral (sulfides, due to intensity decay at around $300^{\circ}-330^{\circ} \mathrm{C}$ ). (b) Curves for the top of the Upper Cretaceous and Eocene, where no "hard" ferromagnetic mineral is present but some sulfides ("intermediate" axis decays before $350^{\circ} \mathrm{C}$ ) and magnetite ("soft" axis decays at around $580^{\circ} \mathrm{C}$ ) are present. $Y$ axis, normalized remanent magnetization; $X$ axis, temperature. 
tou1-4b. "C. des Cañons"
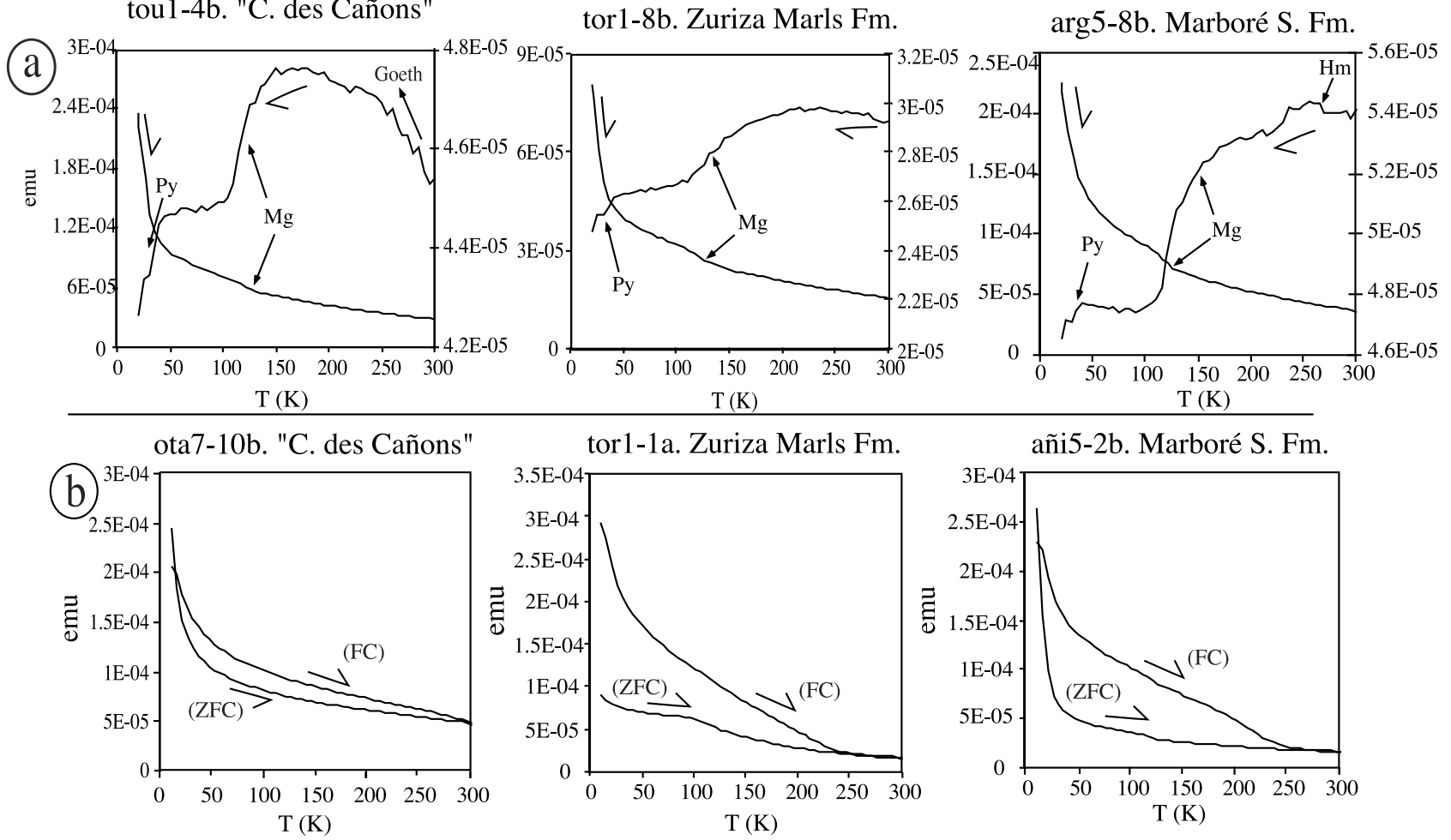

Figure 4. Low-temperature curves. (a) SEEPHECO treatment. First low-temperature saturation isothermal remanent magnetization (LTSIRM) of $2.5 \mathrm{~T}$ at $20 \mathrm{~K}$ is given, followed by heating in a zero field environment with measurement every $5 \mathrm{~K}$ up to $300 \mathrm{~K}$; with saturation isothermal remanent magnetization (SIRM) of $2.5 \mathrm{~T}$ at $300 \mathrm{~K}$ and finally cooling the sample in zero field environment down to $20 \mathrm{~K}$, measuring every $5 \mathrm{~K}$. The curves show the Verwey transition in all rock types $(\mathrm{Mg})$. Pyrrhotite (Py), hematite (Hm) (Morin transition is not clear), and goethite (Goeth) (the remanence in the heating curve increases; Curie temperature is $120^{\circ} \mathrm{C}$ ) can be also present. (b) FCZFC treatment. Cool the sample from $300 \mathrm{~K}$ to $10 \mathrm{~K}$ within an applied field of $2.5 \mathrm{~T}$ (field cooling); heat and measure every $5 \mathrm{~K}$ (FC curve). Then, cool the sample in a zero field environment (zero field cooling) and finally heat and measure every $5 \mathrm{~K}$. The difference in remanence between the two curves above $50 \mathrm{~K}$ can be characteristic of goethite. The fast loss in remanence before the $50 \mathrm{~K}$ in the FC and ZFC curves can indicate the presence of SP grains. Py, transition for pyrrhotite (30-35 K); Mg, Verwey transition for magnetite $(120 \mathrm{~K})$; Hm, Morin transition for hematite $(285 \mathrm{~K})$.

1996), which follows criteria from McElhinny [1964] and software from McFadden [1990].

\section{Paleomagnetic Data}

\subsection{Magnetic Mineralogy}

[16] Samples from the lower part of the Upper Cretaceous (the carbonate platform) show a different ferromagnetic content than the samples from the upper part of the Upper Cretaceous and Eocene (the carbonate-siliciclastic platform and the turbidites). The difference between these two groups in the ferromagnetic content is shown by the IRM and composite IRM analysis. The group 1 (the carbonate platform of the Calcaires des Cañons) is generally less homogeneous, and the IRM curves are not saturated but they show an important contribution of low-coercivity carrier to the NRM. This contribution is revealed by the back-field values less than $-200 \mathrm{mT}$ in 14 of the 19 analyzed specimens (Figure 2a). On the other hand, group 2 shows a more homogeneous magnetic content with a predominance of low-medium coercivity carriers, denoted by the quick saturation of the IRM acquisition curve and by the low values of the coercivity force. The saturation is reached at about $150-250 \mathrm{mT}$, and the coercivity force in the backfield analysis (Hcr) are below $-100 \mathrm{mT}$ in more than $85 \%$ of the studied cases) (Figure 2b).

[17] Stepwise thermal demagnetization of composite IRM [Lowrie, 1990] also reflects the two groups of rocks in terms of ferromagnetic content. Group 1 shows the contribution of hard coercivity carriers that unblock either below $700^{\circ} \mathrm{C}$ or $150^{\circ} \mathrm{C}$. The first unblocking temperature is typical from hematite (found in $85 \%$ of the samples) and the second ones from goethite (in around $25 \%$ of the samples). In some specimens it is possible to see a decay in the 


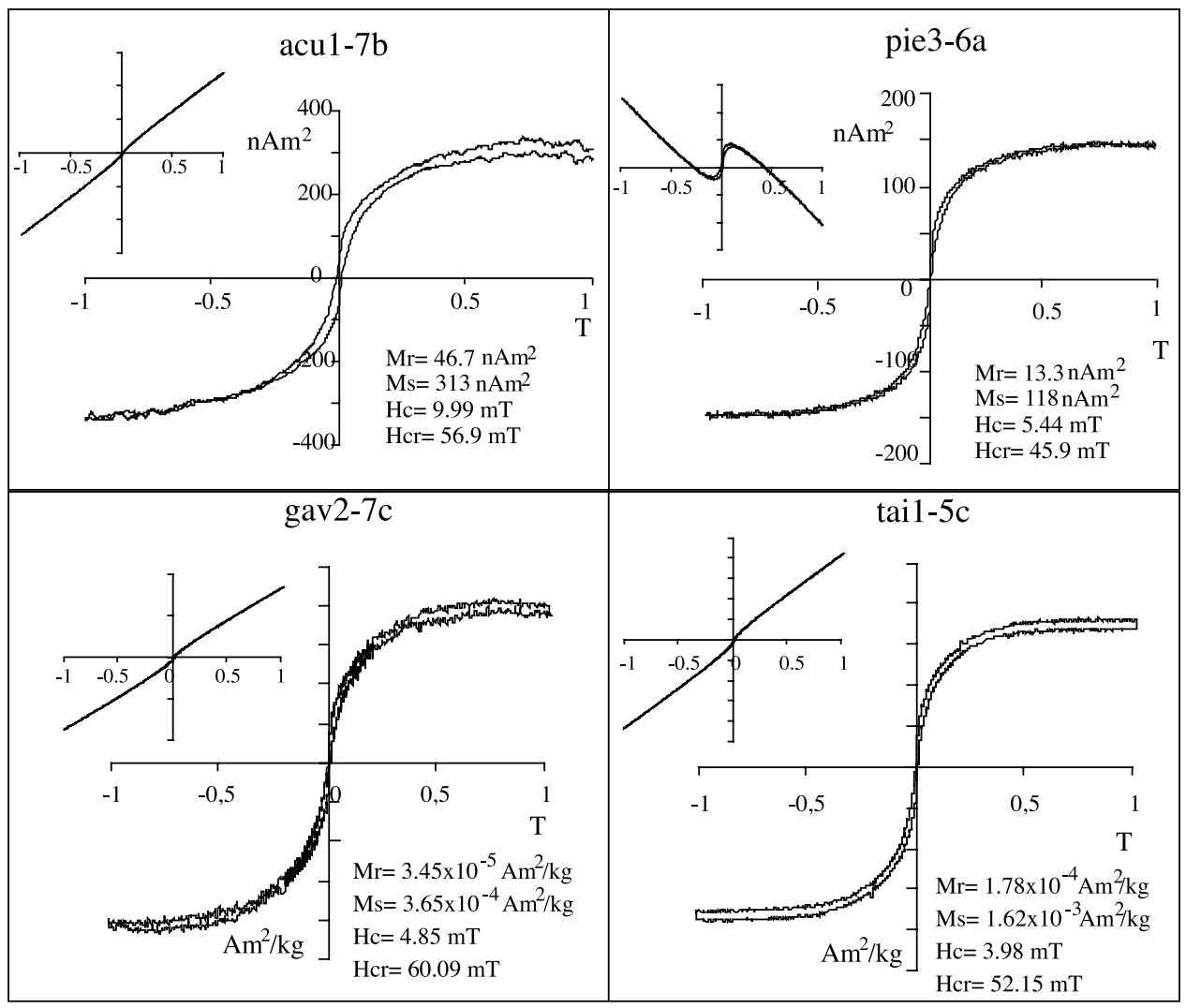

Figure 5. (top) Hysteresis loops from chips and (bottom) standard specimens. The smaller diagrams are the uncorrected loops. Wasp-waisted loops can be observed.

intensity of the medium axis at $300^{\circ}-350^{\circ} \mathrm{C}$ indicating the presence of sulfides. In addition, the decay of the soft axis between $500^{\circ} \mathrm{C}$ and $600^{\circ} \mathrm{C}$ suggests the presence of magnetite (Figure 3a). Group 2 shows a dominance of low- and medium-coercivity carriers, the unblocking temperature is always under $600^{\circ} \mathrm{C}$, and the IRM is dominated by the soft axis $(60-90 \%$ of the IRM), which altogether indicate the presence of magnetite. The decay of the intermediate axis around $300^{\circ}-350^{\circ} \mathrm{C}$ indicates the presence of sulfides as in group 1 (Figure $3 \mathrm{~b}$ ). Although the presence of hard coercivity minerals (hematite and goethite) is detected by the IRM and composite IRM analysis, it is important to note that the thermal cleaning of the NRM of all specimens shows unblocking temperatures $<600^{\circ} \mathrm{C}$, indicating that hematite is not an important remanent magnetization carrier.

[18] Low-temperature analyses indicate the presence of magnetite, since the Verwey transition (at around $120 \mathrm{~K}$ [Verwey and Haayman, 1941]) has been recognized in 45 out of 60 experiments (from microchips and powder samples). In five samples, the Morin transition for hematite is observed (at around $260 \mathrm{~K}$ [Liebermann and Banerjee, 1971]). The sudden decrease in the intensity of the cooling curve below $40 \mathrm{~K}$ strongly suggests the pyrrhotite transition in 29 samples (the transition for pyrrhotite occurs at 30$34 \mathrm{~K}$ [Rochette et al., 1990]). The increase of the intensity in the cooling curve after the saturation isothermal remanent

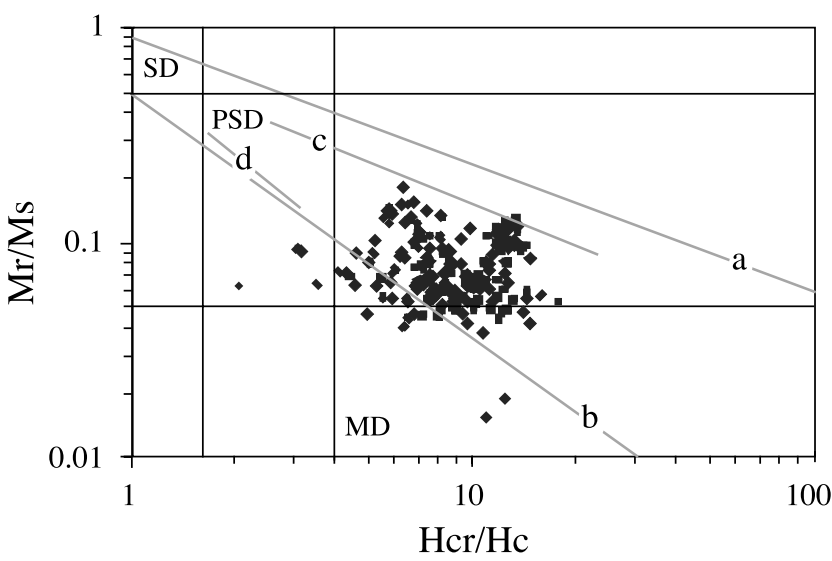

Figure 6. Day diagram. Line a, North American remagnetized limestones [Jackson, 1990]; line b, SD and MD mixture (Parry, 1982); line c, remagnetized limestones [Channell and McCabe, 1994] and remagnetized limestones from Organyà basin [Dinarès-Turell and García-Senz, 2000]; line d, unremagnetized limestones from Channell and McCabe [1994] and Dinarès-Turell and García-Senz [2000]. 
asn3-11a (38) Calcaires des Cañons
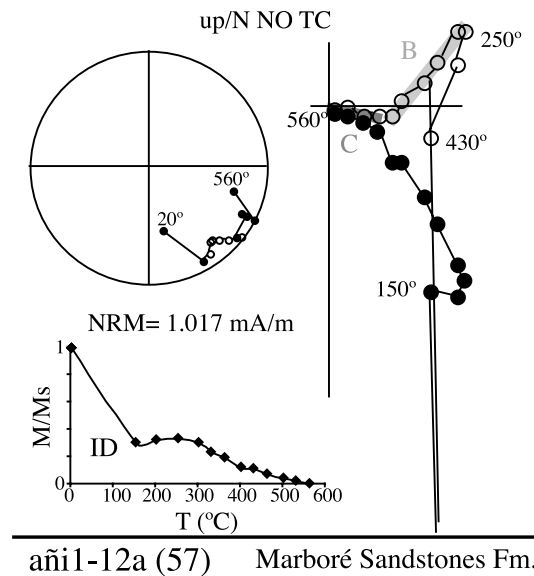

up/W NO TC
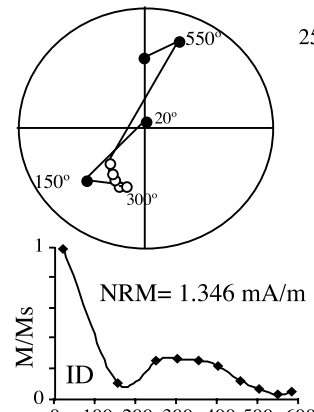

$0 \frac{100200300400500600}{0}$

\begin{tabular}{cc}
$\mathrm{T}\left({ }^{\circ} \mathrm{C}\right)$ \\
\hline $\arg 5-7 \mathrm{a}(5) \quad$ Marboré Sandstones Fm.
\end{tabular}
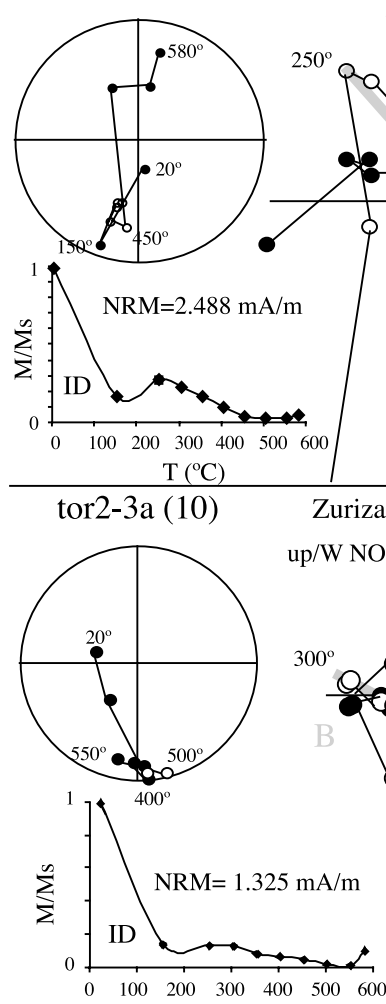

$\mathrm{T}\left({ }^{\circ} \mathrm{C}\right)$
up/W NO TC
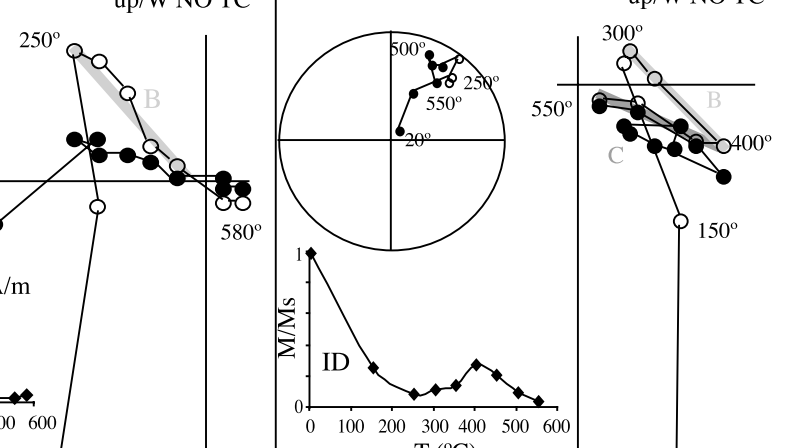

Zuriza Marls Fm. up/W NO TC $/$

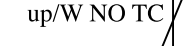

$300^{\circ}$
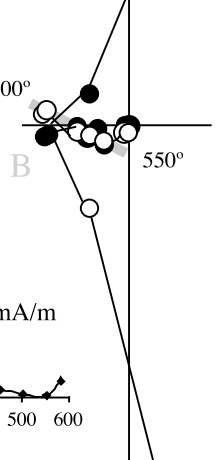
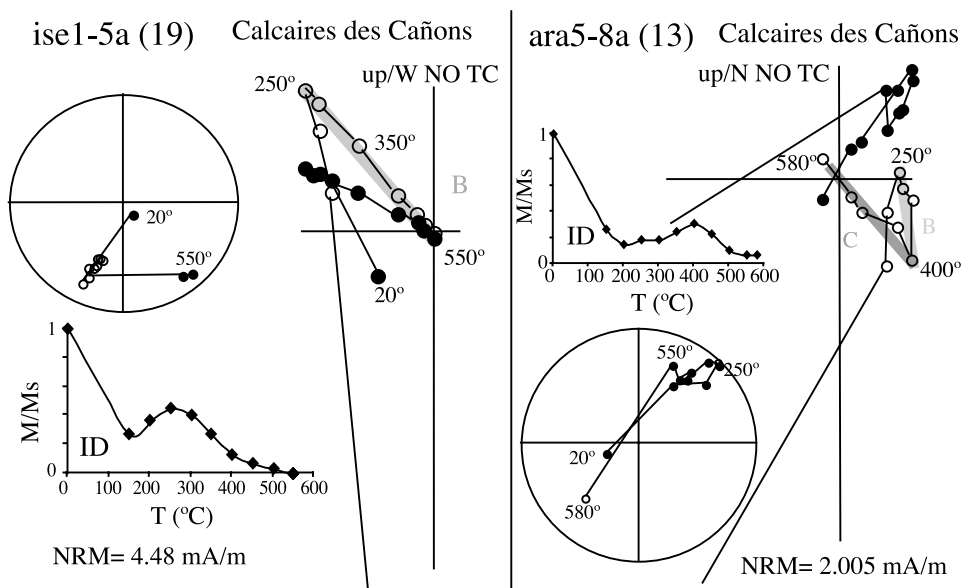

añi2b-1b (58) Marboré Sandstones Fm. agu1-5b (17) Marboré Sands. Fm.

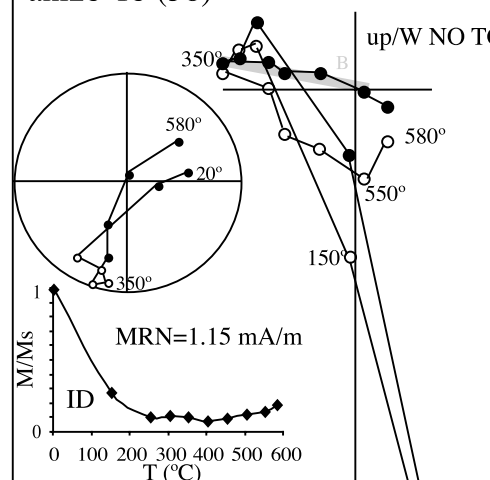

$\mathrm{NRM}=5.433 \mathrm{~mA} / \mathrm{m}$
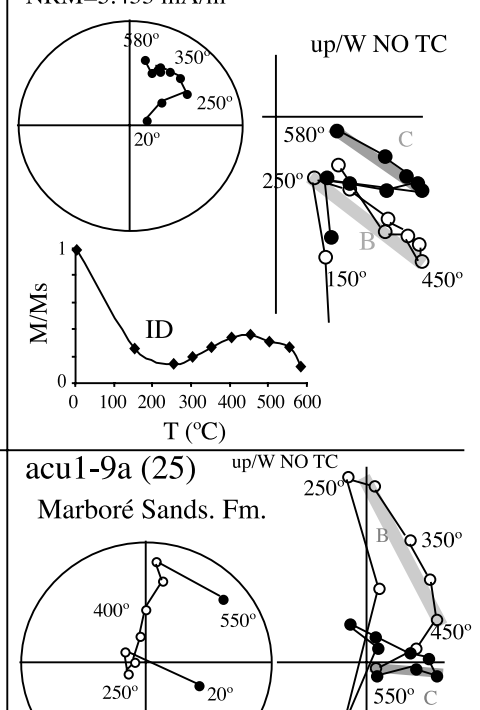

${ }^{1} \mathrm{NRM}=3.079 \mathrm{~mA} / \mathrm{m}$
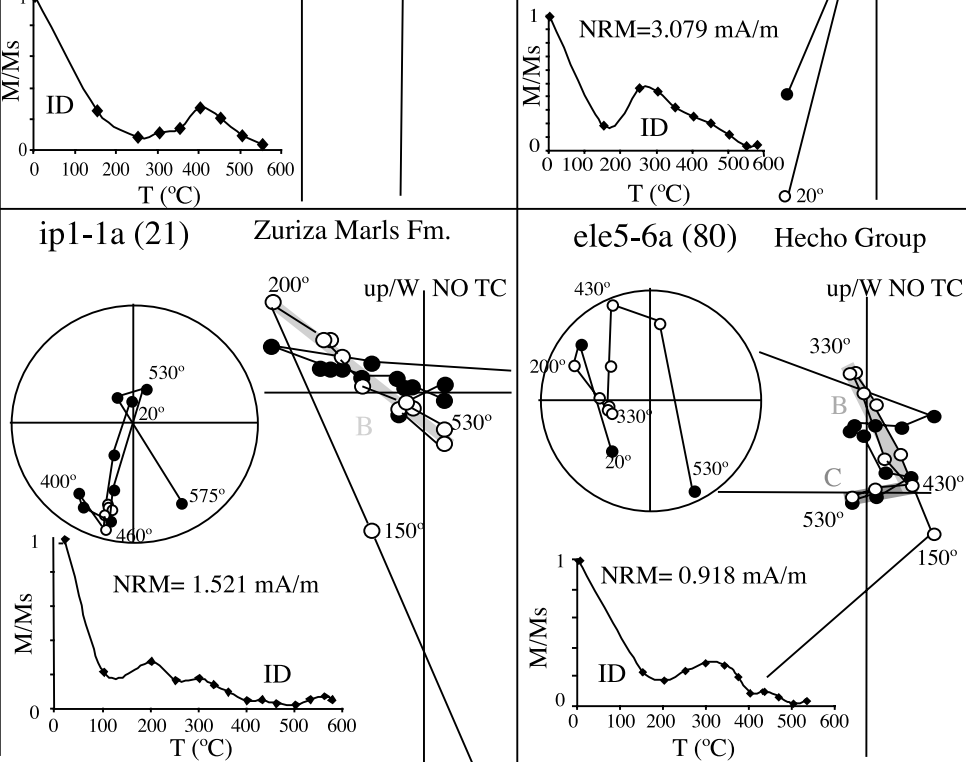

Figure 7 
magnetization suggests the presence of goethite (see Figure 4 for more details).

[19] Hysteresis analyses were done in 100 chips and 30 standard specimens. The loops show a wasp-waisted shape, which is considered a signature of remagnetized carbonates [Jackson, 1990; McCabe and Channell, 1994; Channell and McCabe, 1994] (Figure 5). The Day diagram [Day et al., 1977], constructed from parameters taken from the hysteresis loops and the back field, shows a distribution of the samples between the remagnetized carbonates in North America [Jackson, 1990] and the mixture of singledomain (SD) and multidomain (MD) grains [Parry, 1982] (Figure 6).

[20] Finally, the comparison of the high field susceptibility (measured with MPMS) in about 20 hysteresis loops with the low field susceptibility, measured in sister samples in a Kappabridge KLY-2, suggests that the paramagnetic contribution range between $55 \%$ and $65 \%$, which implies a relatively high ferromagnetic contribution in some of the samples.

\subsection{Components}

[21] In terms of paleomagnetic behavior, despite the difference in the ferromagnetic mineral content, a common description of the magnetic components can be used for the whole data set due to the stable signal. Three distinctive paleomagnetic components have been identified:

[22] 1. For the low-temperature component, unblocking always occurs below $250^{\circ} \mathrm{C}$. In most cases this viscous component is either very similar to the present geomagnetic field or randomly distributed such that it has not been considered (Figure 7).

[23] 2. For the intermediate component, unblocking generally occurs between $250^{\circ} \mathrm{C}$ and $450^{\circ} \mathrm{C}$. This component sometimes persists up to $500^{\circ}-525^{\circ} \mathrm{C}$. This component is widespread (it is defined in $85 \%$ of the analyzed sites) and always presents reverse polarity respect to the considered Tertiary reference (Foldout 1, Figure 8, and Table 1a).

[24] 3. For the high-temperature component, unblocking occurs between $450^{\circ} \mathrm{C}$ and $575^{\circ} \mathrm{C}$. This direction has been clearly recognized in $30 \%$ of the sites. The Eocene turbidites do not show this component The $\mathrm{C}$ component displays two antipodal polarities when tilt corrected (Foldout 1, Figure 8 , and Table $1 \mathrm{~b}$ ).

\subsection{Stability}

[25] The B component shows a remarkably constant orientation (geographic coordinate system). To confirm this apparent postfolding age, the McElhinny [1964] and McFadden [1990] fold test have been carried out for the whole data set. Three regional groups are presented in Table 2 together with the total mean for all sites.

[26] The fold test has been preformed with sites where $\alpha_{95}<15$. The fold test is always negative (postfolding). This result in combination with the occurrence of only one polarity indicates that the B component represents a widespread and postfolding remagnetization (Figure $8 \mathrm{a}$ and Table 2).

[27] On the contrary, the $\mathrm{C}$ component shows two polarities and exhibits a large scatter in geographic coordinates. The fold test confirms the prefolding character of this component (Figure 8b and Table 2). This, together with the appearance of two pseudoantipodal polarities (Figure 8c), points to a primary magnetization acquired during Cretaceous times.

\subsection{Paleomagnetic References}

[28] To quantify the amount of VARs, the Upper Cretaceous and Eocene-Oligocene reference directions have been considered for a common reference point centered in the studied area at $42^{\circ} 41^{\prime} \mathrm{N}, 00^{\circ} 00^{\prime}$ (Gavarnie valley). The Upper Cretaceous reference has a declination and inclination $(\mathrm{D} / \mathrm{I})$ of $002 / 44\left(\alpha_{95}=7\right.$ and $\left.\mathrm{k}=94\right)$ from data compiled by Van der Voo [1993] from Storetvedt et al. [1987], Van der Voo and Zijderveld [1971], Van der Voo [1969], and Storetvedt et al. [1990]. The data correspond to Campanian-Maastriachtian stable Iberia sites in Portugal.

[29] The Bartonian-Rupelian reference (upper Eocenelower Oligocene) is $\mathrm{D} / \mathrm{I}$ of $005 / 47\left(\alpha_{95}=2\right.$ and $\left.\mathrm{k}=16\right)$, calculated from sectors Vic-3 and Vic-2 from Taberner et al. [1999] and from the sectors of Barberá [1999] from sediments of stable Iberia, in the NE part of the Pyrenean foreland (Ebro basin).

\section{Discussion}

\subsection{Magnitude of the Rotation}

[30] The paleomagnetic mean for each site of the B and C components is represented in Foldout 1 (see also Tables 1a and $1 \mathrm{~b}$ ) together with the Upper Cretaceous and EoceneOligocene references. It is observed a general trend of clockwise rotation of the $\mathrm{B}$ component, whereas the rotation of component $\mathrm{C}$ is slightly lower.

[31] As a first approximation in looking at VARs in the area, the means of $\mathrm{B}$ and $\mathrm{C}$ components are represented (Figure 9). The mean of the $\mathrm{B}$ component shows a clockwise rotation of $+13^{\circ}\left(\mathrm{D} / \mathrm{I}\right.$ of $\left.018 / 43 ; \alpha_{95}=4 ; \mathrm{k}=18\right)$. This mean rotation is statistically distinguishable from the Tertiary reference (D/I of $005 / 47 ; \alpha_{95}=2$ and $\mathrm{k}=16$ ). Furthermore, the $\mathrm{C}$ component shows a similar magnitude of rotation: $+8^{\circ}\left(\mathrm{D} / \mathrm{I}\right.$ of $010 / 44 ; \alpha_{95}=8$ and $\left.\mathrm{k}=15\right)$ but in

Figure 7. Paleomagnetic results from the stepwise thermal demagnetization cleaning in situ, in orthogonal and stereographic plots. Diagrams of different lithologies from the Internal Sierras are represented. The magnetic intensity decay (ID) is also shown during the stepwise demagnetization. B and C components are highlighted in gray in the orthogonal diagrams. In the orthogonal diagrams, black (white) circles are projected on the horizontal (vertical) plane. Up/N, north is up; No TC, no tectonic correction. In equal-area projection, black (white) circles are projected on the lower (upper) hemisphere. 


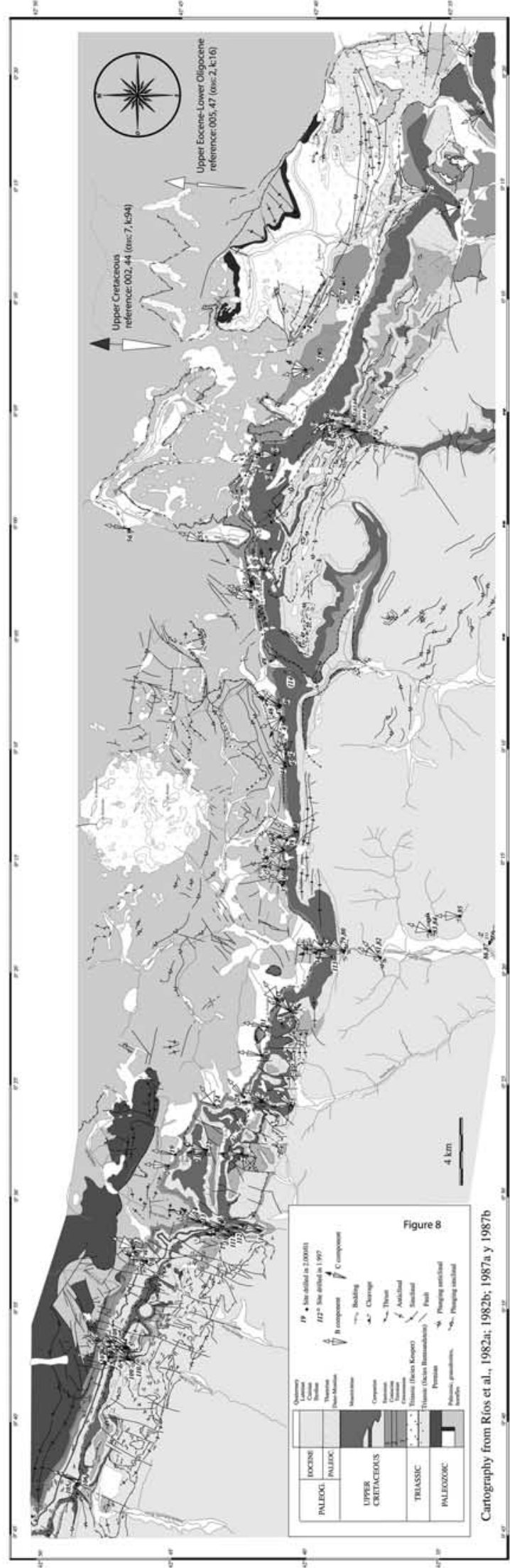

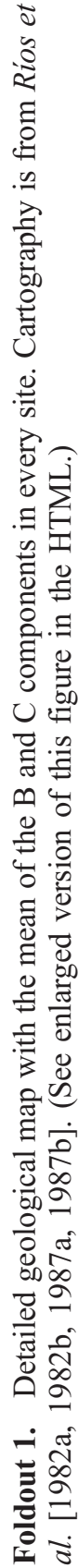




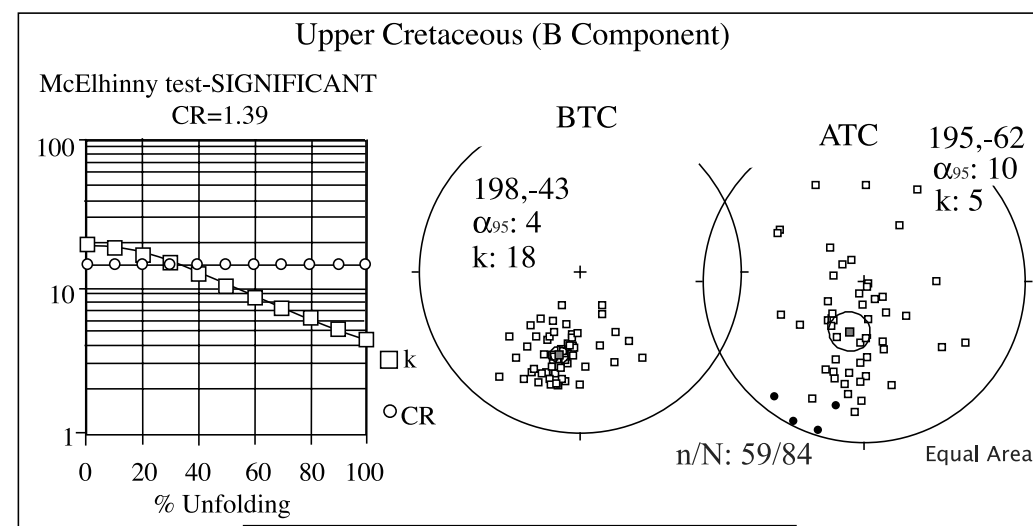

Flysch Eocene (B component)
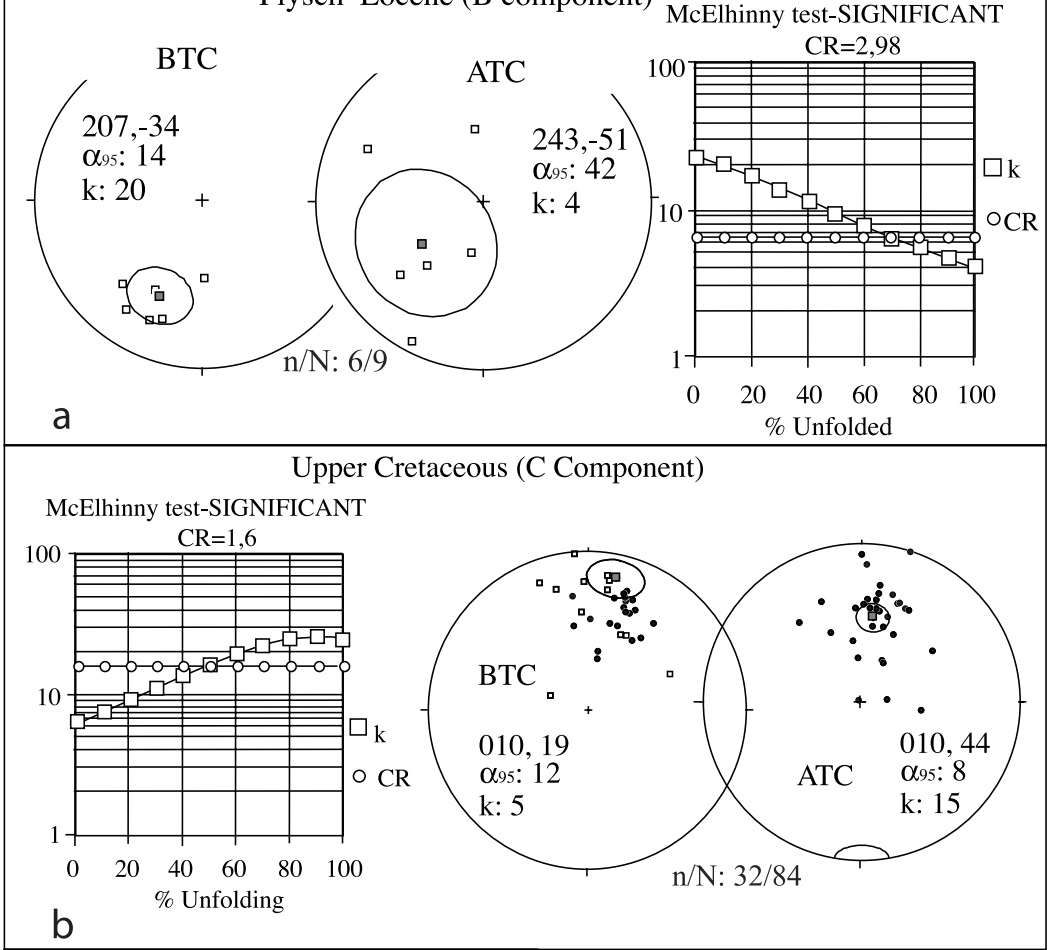

Upper Cretaceous (C Component)

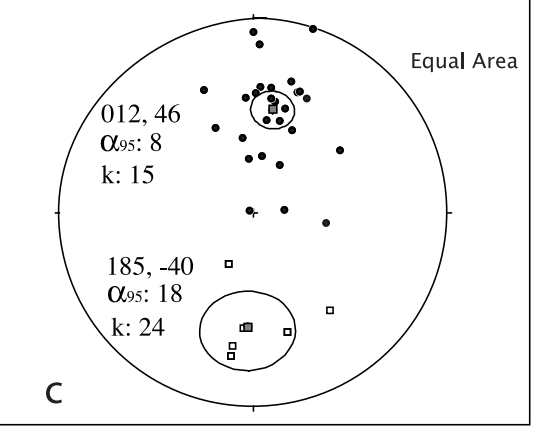

Figure 8. (a) McElhinny fold test for the B component in Upper Cretaceous and Eocene rocks. Equalarea projection is before (BTC) and after (ATC) tectonic correction. In both cases, the McElhinny test is significant and negative. (b) McElhinny fold test for the C component in Upper Cretaceous rocks. Equalarea projection is before and after tectonic correction. The test is significant and positive. (c) Both polarites of the $\mathrm{C}$ component in Upper Cretaceous rocks. 
Table 1a. Paleomagnetic Data of B Component ${ }^{\mathrm{a}}$

\begin{tabular}{|c|c|c|c|c|c|c|c|c|c|c|c|c|}
\hline \multirow[b]{2}{*}{ Site Number } & \multirow[b]{2}{*}{ Latitude } & \multirow[b]{2}{*}{ Longitude } & \multirow[b]{2}{*}{ Site } & \multirow[b]{2}{*}{$\mathrm{n} / \mathrm{N}$} & \multicolumn{4}{|c|}{ "In situ" (BTC) } & \multirow[b]{2}{*}{ So Stike } & \multirow[b]{2}{*}{ So Dip } & \multicolumn{2}{|c|}{ ATC } \\
\hline & & & & & $\mathrm{D}$ & I & $\alpha_{95}$ & $\mathrm{k}$ & & & $\mathrm{D}$ & I \\
\hline & & & aires des & ñons $(C \mathrm{C}$ & omani & -Santo & & & & & & \\
\hline 11 & $42^{\circ} 46^{\prime} 34^{\prime \prime} .8 \mathrm{~N}$ & $0^{\circ} 32^{\prime} 28^{\prime \prime} .6 \mathrm{~W}$ & CAN-1 & - & - & - & - & - & 127 & $37 \mathrm{~S}$ & - & - \\
\hline 12 & $42^{\circ} 46^{\prime} 38^{\prime \prime} \mathrm{N}$ & $0^{\circ} 32^{\prime} 19^{\prime \prime} .8 \mathrm{~W}$ & CAN-2 & $4 / 7$ & 205 & -29 & 27 & 9 & 120 & $58 \mathrm{~S}$ & 155 & -85 \\
\hline 13 & $42^{\circ} 44^{\prime} 10^{\prime \prime} .4 \mathrm{~N}$ & $0^{\circ} 31^{\prime} 20^{\prime \prime} .4 \mathrm{~W}$ & ARA-5 & $14 / 14$ & 189 & -43 & 6 & 44 & 114 & $20 \mathrm{~S}$ & 181 & -62 \\
\hline 14 & $42^{\circ} 44^{\prime} 26^{\prime \prime} .4$ & $0^{\circ} 31^{\prime} 10^{\prime \prime} .5 \mathrm{~W}$ & ARA-6 & $14 / 16$ & 206 & -57 & 7 & 35 & 160 & $39 \mathrm{~S}$ & 128 & -64 \\
\hline 19 & $42^{\circ} 45^{\prime} 1^{\prime \prime} .6 \mathrm{~N}$ & $0^{\circ} 28^{\prime} 23^{\prime \prime} .2 \mathrm{~W}$ & ISE-1 & $6 / 9$ & 191 & -45 & 6 & 100 & 155 & $8 \mathrm{~S}$ & 184 & -50 \\
\hline 20 & $42^{\circ} 45^{\prime} 11^{\prime \prime} .2 \mathrm{~N}$ & $0^{\circ} 28^{\prime} 54^{\prime \prime} \mathrm{W}$ & ISE-2 & $7 / 8$ & 184 & -60 & 13 & 18 & 130 & $20 \mathrm{~S}$ & 145 & -72 \\
\hline 24 & $42^{\circ} 43^{\prime} 56^{\prime \prime} \mathrm{N}$ & $0^{\circ} 26^{\prime} 6^{\prime \prime} \mathrm{W}$ & PIE-6 & $5 / 7$ & 234 & -18 & 38 & 4 & 38 & $15 \mathrm{~W}$ & 229 & -22 \\
\hline 28 & $42^{\circ} 42^{\prime} 44^{\prime \prime} .2 \mathrm{~N}$ & $0^{\circ} 25^{\prime} 44^{\prime \prime} \mathrm{W}$ & PIE-5 & $10 / 10$ & 229 & -40 & 10 & 20 & 100 & $13 \mathrm{~S}$ & 238 & -50 \\
\hline 30 & $42^{\circ} 42^{\prime} 23^{\prime \prime} .8 \mathrm{~N}$ & $0^{\circ} 23^{\prime} 51^{\prime \prime} .8 \mathrm{~W}$ & PIE-3 & $10 / 10$ & 189 & -57 & 9 & 30 & 87 & $45 \mathrm{~S}$ & 330 & -76 \\
\hline 31 & $42^{\circ} 41^{\prime} 41^{\prime \prime} .8 \mathrm{~N}$ & $0^{\circ} 22^{\prime} 47^{\prime \prime} .2 \mathrm{~W}$ & PIE-2 & $7 / 8$ & 190 & -53 & 8 & 48 & 100 & $26 \mathrm{~S}$ & 189 & -79 \\
\hline 32 & $42^{\circ} 41^{\prime} 19^{\prime \prime} .4 \mathrm{~N}$ & $0^{\circ} 21^{\prime} 32^{\prime \prime} .4 \mathrm{~W}$ & PIE-1 & $4 / 7$ & 234 & -31 & 30 & 8 & 100 & $20 \mathrm{~S}$ & 246 & -44 \\
\hline 34 & $42^{\circ} 40^{\prime} 7^{\prime \prime} .4 \mathrm{~N}$ & $0^{\circ} 19^{\prime} 14^{\prime \prime} .9 \mathrm{~W}$ & ELE-1 & $7 / 13$ & 193 & -40 & 8 & 56 & 88 & $59 \mathrm{~S}$ & 309 & -74 \\
\hline 36 & $42^{\circ} 41^{\prime} 21^{\prime \prime} \mathrm{N}$ & $0^{\circ} 15^{\prime} 55^{\prime \prime} \mathrm{W}$ & ASN-1 & $6 / 8$ & 191 & -29 & 10 & 42 & 74 & $45 \mathrm{~S}$ & 226 & -63 \\
\hline 37 & $42^{\circ} 41^{\prime} 20^{\prime \prime} \mathrm{N}$ & $0^{\circ} 15^{\prime} 57^{\prime \prime} .7 \mathrm{~W}$ & ASN-2 & $5 / 8$ & 220 & -43 & 7 & 24 & 125 & $32 \mathrm{~S}$ & 229 & -75 \\
\hline 38 & $42^{\circ} 41^{\prime} 16^{\prime \prime} \mathrm{N}$ & $0^{\circ} 15^{\prime} 23^{\prime \prime} .5 \mathrm{~W}$ & ASN-3 & $9 / 10$ & 207 & -32 & 10 & 23 & 96 & $45 \mathrm{~S}$ & 256 & -71 \\
\hline 39 & $42^{\circ} 41^{\prime} 8^{\prime \prime} .2 \mathrm{~N}$ & $0^{\circ} 14^{\prime} 28^{\prime \prime} .5 \mathrm{~W}$ & TEN-1 & $10 / 10$ & 202 & -28 & 10 & 24 & 96 & $40 \mathrm{~S}$ & 219 & -64 \\
\hline 41 & $42^{\circ} 41^{\prime} 16^{\prime \prime} .2 \mathrm{~N}$ & $0^{\circ} 14^{\prime} 54^{\prime \prime} .9 \mathrm{~W}$ & TEN-3 & $5 / 10$ & 225 & -53 & 10 & 47 & 74 & $65 \mathrm{~S}$ & 302 & -37 \\
\hline 42 & $42^{\circ} 41^{\prime} 16^{\prime \prime} .2 \mathrm{~N}$ & $0^{\circ} 9^{\prime} 27^{\prime \prime} .8 \mathrm{~W}$ & OTA-1 & $3 / 5$ & 253 & -33 & 44 & 6 & 80 & $55 \mathrm{~S}$ & 285 & -23 \\
\hline 43 & $42^{\circ} 41^{\prime} 24^{\prime \prime} .2 \mathrm{~N}$ & $0^{\circ} 8^{\prime} 48^{\prime \prime} .7 \mathrm{~W}$ & OTA-2 & $6 / 8$ & 155 & -39 & 21 & 10 & 82 & $44 \mathrm{~S}$ & 105 & -75 \\
\hline 44 & $42^{\circ} 41^{\prime} 19^{\prime \prime} .4 \mathrm{~N}$ & $0^{\circ} 11^{\prime} 8^{\prime \prime} .3 \mathrm{~W}$ & OTA-3 & $4 / 6$ & 255 & -53 & 26 & 10 & 103 & $39 \mathrm{~S}$ & 311 & -53 \\
\hline 45 & $42^{\circ} 41^{\prime} 14^{\prime \prime} .6 \mathrm{~N}$ & $0^{\circ} 11^{\prime} 9^{\prime \prime} .4 \mathrm{~W}$ & OTA-4 & $5 / 7$ & 228 & -54 & 19 & 12 & 80 & $85 \mathrm{~S}$ & 201 & 14 \\
\hline 46 & $42^{\circ} 41^{\prime} 40^{\prime \prime} .2 \mathrm{~N}$ & $0^{\circ} 7^{\prime} 45^{\prime \prime} .8 \mathrm{~W}$ & OTA-5 & $10 / 10$ & 219 & -19 & 10 & 22 & 125 & $30 \mathrm{~N}$ & 219 & 11 \\
\hline 47 & $42^{\circ} 41^{\prime} 43^{\prime \prime} .4 \mathrm{~N}$ & $0^{\circ} 7^{\prime} 41^{\prime \prime} .4 \mathrm{~W}$ & OTA-6 & $7 / 10$ & 207 & -34 & 13 & 19 & 118 & $68 \mathrm{~N}(\mathrm{i})$ & 32 & -33 \\
\hline 48 & $42^{\circ} 41^{\prime} 45^{\prime \prime} \mathrm{N}$ & $0^{\circ} 7^{\prime} 43^{\prime \prime} .6 \mathrm{~W}$ & OTA-7 & $9 / 10$ & 209 & -26 & 10 & 24 & 116 & $30 \mathrm{~N}(\mathrm{i})$ & 23 & -4 \\
\hline 49 & $42^{\circ} 41^{\prime} 45^{\prime \prime} .2$ & $0^{\circ} 6^{\prime} 14^{\prime \prime} \mathrm{W}$ & BUJ-2 & - & - & - & - & - & 80 & $50 \mathrm{~S}$ & - & - \\
\hline 50 & $42^{\circ} 42^{\prime} 25^{\prime \prime} \mathrm{N}$ & $0^{\circ} 3^{\prime} 18^{\prime \prime} .8 \mathrm{~W}$ & TOU-1 & $6 / 8$ & 200 & -35 & 29 & 5 & 65 & $73 \mathrm{~N}$ & 194 & 22 \\
\hline 51 & $42^{\circ} 42^{\prime} 20^{\prime \prime} .2 \mathrm{~N}$ & $0^{\circ} 2^{\prime} 12^{\prime \prime} \mathrm{W}$ & TOU-2 & $5 / 8$ & 195 & -36 & 8 & 69 & 84 & $74 \mathrm{~S}$ & 315 & -63 \\
\hline 52 & $42^{\circ} 42^{\prime} 15^{\prime \prime} .4 \mathrm{~N}$ & $0^{\circ} 3^{\prime} 39^{\prime \prime} \mathrm{W}$ & TOU-3 & - & - & - & - & - & 54 & $57 \mathrm{~S}$ & - & - \\
\hline 55 & $42^{\circ} 44^{\prime} 48^{\prime \prime} .3 \mathrm{~N}$ & $0^{\circ} 0^{\prime} 4^{\prime \prime} .4 \mathrm{E}$ & GAV-1 & $3 / 5$ & 200 & -33 & 18 & 31 & 140 & $35 \mathrm{~N}$ & 205 & -2 \\
\hline 56 & $42^{\circ} 46^{\prime} 52^{\prime \prime} .8 \mathrm{~N}$ & $0^{\circ} 0^{\prime} 38^{\prime \prime} .5 \mathrm{E}$ & GAV-2 & $9 / 10$ & 190 & -53 & 10 & 25 & 120 & $60 \mathrm{~N}$ & 201 & 3 \\
\hline 70 & $42^{\circ} 40^{\prime} 27^{\prime \prime} .4 \mathrm{~N}$ & $0^{\circ} 6^{\prime} 36^{\prime \prime} .8 \mathrm{E}$ & PIN-1 & $5 / 6$ & 168 & -51 & 31 & 6 & 134 & $36 \mathrm{~S}$ & 116 & -57 \\
\hline 71 & $42^{\circ} 39^{\prime} 53^{\prime \prime} \mathrm{N}$ & $0^{\circ} 7^{\prime} 28^{\prime \prime} .7 \mathrm{E}$ & PIN-2 & - & - & - & - & - & 100 & $40 \mathrm{~S}$ & - & - \\
\hline 72 & $42^{\circ} 38^{\prime} 40^{\prime \prime} \mathrm{N}$ & $0^{\circ} 10^{\prime} 6^{\prime \prime} .6 \mathrm{E}$ & PIN-3 & - & - & - & - & - & 122 & $41 \mathrm{~S}$ & - & - \\
\hline 73 & $42^{\circ} 39^{\prime} 37^{\prime \prime} \mathrm{N}$ & $0^{\circ} 9^{\prime} 51^{\prime \prime} .1 \mathrm{E}$ & PIN-4 & - & - & - & - & - & 2 & $10 \mathrm{E}$ & - & - \\
\hline 74 & $42^{\circ} 40^{\prime} 57^{\prime \prime} \mathrm{N}$ & $0^{\circ} 8^{\prime} 10^{\prime \prime} \mathrm{E}$ & CHI-1 & - & - & - & - & - & 130 & $27 \mathrm{~N}$ & - & - \\
\hline 75 & $42^{\circ} 36^{\prime} 12^{\prime \prime} .8 \mathrm{~N}$ & $0^{\circ} 14^{\prime} 46^{\prime \prime} .8 \mathrm{E}$ & CIN-1 & $3 / 5$ & 189 & -59 & 15 & 45 & 114 & $25 \mathrm{~S}$ & 150 & -81 \\
\hline 77 & $42^{\circ} 34^{\prime} 57^{\prime \prime} \mathrm{N}$ & $0^{\circ} 19^{\prime} 35^{\prime \prime} \mathrm{E}$ & QIN-1 & $5 / 7$ & 218 & -29 & 17 & 20 & 125 & $25 \mathrm{~W}$ & 206 & -50 \\
\hline & & & Zuriza Ma & (Santont & n-Maa & ichtiat & & & & & & \\
\hline 9 & $42^{\circ} 46^{\prime} 15^{\prime \prime} .2 \mathrm{~N}$ & $0^{\circ} 33^{\prime} 2^{\prime \prime} .7 \mathrm{~W}$ & TOR-1 & $6 / 8$ & 202 & -34 & 15 & 13 & 110 & $50 \mathrm{~S}$ & 217 & -84 \\
\hline 10 & $42^{\circ} 46^{\prime} 10^{\prime \prime} .4 \mathrm{~N}$ & $0^{\circ} 33^{\prime} 6^{\prime \prime} \mathrm{W}$ & TOR-2 & $6 / 9$ & 211 & -47 & 28 & 5 & 110 & $22 \mathrm{~N}$ & 208 & -25 \\
\hline 21 & $42^{\circ} 43^{\prime} 49^{\prime \prime} .8 \mathrm{~N}$ & $0^{\circ} 28^{\prime} 23^{\prime \prime} .2 \mathrm{~W}$ & IP-1 & $9 / 10$ & 199 & -45 & 9 & 27 & 125 & $43 \mathrm{~S}$ & 131 & -78 \\
\hline 22 & $42^{\circ} 43^{\prime} 45^{\prime \prime} \mathrm{N}$ & $0^{\circ} 28^{\prime} 42^{\prime \prime} \mathrm{W}$ & IP-2 & $10 / 10$ & 193 & -31 & 7 & 45 & 114 & $5 \mathrm{~S}$ & 192 & -36 \\
\hline 28 & $42^{\circ} 42^{\prime} 44^{\prime \prime} .2 \mathrm{~N}$ & $0^{\circ} 25^{\prime} 44^{\prime \prime} \mathrm{W}$ & PIE-5 & $10 / 10$ & 229 & -40 & 10 & 20 & 100 & $13 \mathrm{~S}$ & 238 & -50 \\
\hline 105 & $42^{\circ} 48^{\prime} 1^{\prime \prime} .6 \mathrm{~N}$ & $0^{\circ} 48^{\prime} 15^{\prime \prime} .5 \mathrm{~W}$ & ZUR-3 & $8 / 9$ & 204 & -59 & 4 & 172 & 100 & $20 \mathrm{~S}$ & 225 & -77 \\
\hline 107 & $42^{\circ} 47^{\prime} 8^{\prime \prime} .8 \mathrm{~N}$ & $0^{\circ} 36^{\prime} 24^{\prime \prime} \mathrm{W}$ & MG-1 & $5 / 5$ & 227 & -3 & 27 & 7 & 107 & $89 \mathrm{~S}$ & 291 & -60 \\
\hline 108 & $42^{\circ} 47^{\prime} 20^{\prime \prime} \mathrm{N}$ & $0^{\circ} 36^{\prime} 32^{\prime \prime} .2 \mathrm{~W}$ & MG-2 & $10 / 10$ & 197 & -32 & 8 & 36 & 114 & $60 \mathrm{~S}$ & 94 & -84 \\
\hline & & & boré Sand & nes Forn & tion & zastric & & & & & & \\
\hline 1 & $42^{\circ} 47^{\prime} 0^{\prime \prime} .8 \mathrm{~N}$ & $0^{\circ} 36^{\prime} 55^{\prime \prime} .6 \mathrm{~W}$ & ARG-1 & $8 / 9$ & 193 & -48 & 12 & 19 & 85 & $18 \mathrm{~N}$ & 189 & -30 \\
\hline 2 & $42^{\circ} 47^{\prime} \mathrm{N}$ & $0^{\circ} 37^{\prime} \mathrm{W}$ & ARG-2 & $6 / 8$ & 186 & -52 & 12 & 26 & 105 & $20 \mathrm{~S}$ & 177 & -72 \\
\hline 3 & $42^{\circ} 46^{\prime} 38^{\prime \prime} \mathrm{N}$ & $0^{\circ} 36^{\prime} 56^{\prime \prime} .6 \mathrm{~W}$ & ARG-3 & $8 / 10$ & 190 & -36 & 16 & 11 & 80 & $24 \mathrm{~S}$ & 202 & -58 \\
\hline 4 & $42^{\circ} 46^{\prime} 52^{\prime \prime} .2 \mathrm{~N}$ & $0^{\circ} 36^{\prime} 22^{\prime \prime} \mathrm{W}$ & ARG-4 & $9 / 10$ & 216 & -50 & 12 & 21 & 40 & $12 \mathrm{~N}$ & 103 & -48 \\
\hline 5 & $42^{\circ} 46^{\prime} 44^{\prime \prime} .8 \mathrm{~N}$ & $0^{\circ} 36^{\prime} 18^{\prime \prime} \mathrm{W}$ & ARG-5 & $6 / 9$ & 208 & -52 & 12 & 27 & 50 & $18 \mathrm{~N}$ & 190 & -43 \\
\hline 6 & $42^{\circ} 47^{\prime} 15^{\prime \prime} .6 \mathrm{~N}$ & $0^{\circ} 37^{\prime} 25^{\prime \prime} \mathrm{W}$ & ARG-6 & $8 / 10$ & 205 & -44 & 12 & 20 & 155 & $25 \mathrm{~W}$ & 179 & -59 \\
\hline 7 & $42^{\circ} 46^{\prime} 55^{\prime \prime} .2 \mathrm{~N}$ & $0^{\circ} 37^{\prime} 10^{\prime \prime} .6 \mathrm{~W}$ & ARG-7 & $10 / 10$ & 194 & -49 & 8 & 32 & 140 & $18 \mathrm{~S}$ & 175 & -62 \\
\hline 8 & $42^{\circ} 46^{\prime} 50^{\prime \prime} .6 \mathrm{~N}$ & $0^{\circ} 37^{\prime} 15^{\prime \prime} \mathrm{W}$ & ARG-8 & $8 / 9$ & 217 & -43 & 10 & 26 & 115 & $25 \mathrm{~S}$ & 229 & -67 \\
\hline 15 & $42^{\circ} 43^{\prime} 35^{\prime \prime} .2 \mathrm{~N}$ & $0^{\circ} 30^{\prime} 56^{\prime \prime} .2 \mathrm{~W}$ & ARA-7 & $7 / 9$ & 189 & -33 & 15 & 13 & 147 & $10 \mathrm{~W}$ & 184 & -39 \\
\hline 16 & $42^{\circ} 42^{\prime} 20^{\prime \prime} .2 \mathrm{~N}$ & $0^{\circ} 31^{\prime} 36^{\prime \prime} .9 \mathrm{~W}$ & ARA-8 & $4 / 9$ & 205 & -48 & 19 & 18 & 110 & $25 \mathrm{~S}$ & 227 & -76 \\
\hline 17 & $42^{\circ} 43^{\prime} 25^{\prime \prime} .8 \mathrm{~N}$ & $0^{\circ} 32^{\prime} 27^{\prime \prime} .6 \mathrm{~W}$ & AGU-1 & $6 / 8$ & 191 & -29 & 7 & 63 & 40 & $15 \mathrm{~W}$ & 185 & -21 \\
\hline 18 & $42^{\circ} 43^{\prime} 22^{\prime \prime} .6 \mathrm{~N}$ & $0^{\circ} 32^{\prime} 16^{\prime \prime} .6 \mathrm{~W}$ & AGU-2 & $9 / 10$ & 196 & -29 & 7 & 48 & 10 & $26 \mathrm{~W}$ & 182 & -29 \\
\hline 111 & $42^{\circ} 42^{\prime} 57^{\prime \prime} .6 \mathrm{~N}$ & $0^{\circ} 32^{\prime \prime} \mathrm{W}$ & ARA-1 & $5 / 5$ & 191 & -28 & 23 & 5 & 12 & $16 \mathrm{~N}$ & 187 & -15 \\
\hline 112 & $42^{\circ} 43^{\prime} 20^{\prime \prime} .7 \mathrm{~N}$ & $0^{\circ} 31^{\prime} 44^{\prime \prime} .6 \mathrm{~W}$ & ARA-2 & $10 / 10$ & 191 & -34 & 6 & 61 & 46 & $13 \mathrm{~S}$ & 189 & -41 \\
\hline 23 & $42^{\circ} 42^{\prime} 40^{\prime \prime} .2 \mathrm{~N}$ & $0^{\circ} 28^{\prime} 37^{\prime \prime} .6 \mathrm{~W}$ & COL-1 & $5 / 9$ & 229 & -37 & 32 & 5 & 104 & $13 \mathrm{~N}$ & 225 & 26 \\
\hline 25 & $42^{\circ} 42^{\prime} 4^{\prime \prime} .8 \mathrm{~N}$ & $0^{\circ} 25^{\prime} 6^{\prime \prime} .6 \mathrm{~W}$ & ACU-1 & $9 / 10$ & 223 & -59 & 12 & 21 & 88 & $78 \mathrm{~S}$ & 333 & -32 \\
\hline 26 & $42^{\circ} 42^{\prime} 12^{\prime \prime} .8 \mathrm{~N}$ & $0^{\circ} 25^{\prime} 6^{\prime \prime} .6 \mathrm{~W}$ & ACU-2 & $10 / 10$ & 212 & -62 & 6 & 54 & 88 & $4 \mathrm{~N}$ & 208 & -58 \\
\hline
\end{tabular}


Table 1a. (continued)

\begin{tabular}{|c|c|c|c|c|c|c|c|c|c|c|c|c|}
\hline \multirow[b]{2}{*}{ Site Number } & \multirow[b]{2}{*}{ Latitude } & \multirow[b]{2}{*}{ Longitude } & \multirow[b]{2}{*}{ Site } & \multirow[b]{2}{*}{$\mathrm{n} / \mathrm{N}$} & \multicolumn{4}{|c|}{ "In situ" (BTC) } & \multirow[b]{2}{*}{ So Stike } & \multirow[b]{2}{*}{ So Dip } & \multicolumn{2}{|c|}{ ATC } \\
\hline & & & & & D & I & $\alpha_{95}$ & $\mathrm{k}$ & & & D & I \\
\hline 27 & $42^{\circ} 42^{\prime} 27^{\prime \prime} .2 \mathrm{~N}$ & $0^{\circ} 25^{\prime} 6^{\prime \prime} .6 \mathrm{~W}$ & ACU-3 & $10 / 10$ & 175 & -22 & 7 & 46 & 120 & $25 \mathrm{~S}$ & 165 & -42 \\
\hline 29 & $42^{\circ} 40^{\prime} 48^{\prime \prime} .6 \mathrm{~N}$ & $0^{\circ} 21^{\prime} 56^{\prime \prime} .6 \mathrm{~W}$ & PIE-4 & $4 / 6$ & 206 & -34 & 45 & 4 & 3 & $35 \mathrm{~S}$ & 220 & -16 \\
\hline 33 & $42^{\circ} 41^{\prime} 9^{\prime \prime} .8 \mathrm{~N}$ & $0^{\circ} 22^{\prime} 10^{\prime \prime} .5 \mathrm{~W}$ & TEL-1 & - & - & - & - & - & 150 & $24 \mathrm{~S}$ & - & - \\
\hline 35 & $42^{\circ} 39^{\prime} 56^{\prime \prime} \mathrm{N}$ & $0^{\circ} 19^{\prime} 9^{\prime \prime} .4 \mathrm{~W}$ & ELE-2 & $6 / 8$ & 199 & -41 & 26 & 7 & 150 & $63 \mathrm{~S}$ & 117 & -54 \\
\hline 40 & $42^{\circ} 40^{\prime} 58^{\prime \prime} .4 \mathrm{~N}$ & $0^{\circ} 14^{\prime} 6^{\prime \prime} .6 \mathrm{~W}$ & TEN-2 & $3 / 5$ & 175 & -24 & 41 & 7 & 90 & $57 \mathrm{~S}$ & 151 & -80 \\
\hline 53 & $42^{\circ} 42^{\prime} 10^{\prime \prime} .6 \mathrm{~N}$ & $0^{\circ} 1^{\prime} 43^{\prime \prime} .4 \mathrm{~W}$ & TOU-4 & $3 / 6$ & 160 & -41 & 11 & 84 & 80 & $89 \mathrm{~N}(\mathrm{i})$ & 0 & -39 \\
\hline 54 & $42^{\circ} 41^{\prime} 59^{\prime \prime} .8 \mathrm{~N}$ & $0^{\circ} 1^{\prime} 47^{\prime \prime} .8 \mathrm{~W}$ & TAI-1 & $9 / 10$ & 179 & -43 & 6 & 58 & 70 & $55 \mathrm{~S}$ & 294 & -72 \\
\hline 57 & $42^{\circ} 38^{\prime} 12^{\prime \prime} .2 \mathrm{~N}$ & $0^{\circ} 3^{\prime} 24^{\prime \prime} .6 \mathrm{E}$ & AÑ $I-1$ & $9 / 10$ & 196 & -43 & 6 & 70 & 9 & $10 \mathrm{E}$ & 205 & -41 \\
\hline 58 & $42^{\circ} 38^{\prime} 12^{\prime \prime} .2 \mathrm{~N}$ & $0^{\circ} 3^{\prime} 29^{\prime \prime} \mathrm{E}$ & AÑI-2 & - & - & - & - & - & 9 & $10 \mathrm{E}$ & - & - \\
\hline 59 & $42^{\circ} 39^{\prime} 53^{\prime \prime} .6 \mathrm{~N}$ & $0^{\circ} 4^{\prime} 19^{\prime \prime} .8 \mathrm{E}$ & AÑI-3 & - & - & - & - & - & 75 & $6 \mathrm{~S}$ & - & - \\
\hline 60 & $42^{\circ} 39^{\prime} 36^{\prime \prime} .8 \mathrm{~N}$ & $0^{\circ} 4^{\prime} 35^{\prime \prime} .2 \mathrm{E}$ & AÑI-4f1 & $5 / 9$ & 190 & -23 & 19 & 14 & 122 & $40 \mathrm{~S}$ & 171 & -66 \\
\hline 61 & $42^{\circ} 39^{\prime} 36^{\prime \prime} .8 \mathrm{~N}$ & $0^{\circ} 4^{\prime} 35^{\prime \prime} .2 \mathrm{E}$ & AÑI- $4 \mathrm{f} 2$ & $5 / 7$ & 144 & -36 & 12 & 32 & 130 & $20 \mathrm{~S}$ & 129 & -38 \\
\hline 62 & $42^{\circ} 39^{\prime} 16^{\prime \prime} \mathrm{N}$ & $0^{\circ} 4^{\prime} 13^{\prime \prime} .2 \mathrm{E}$ & AÑI-5 & $6 / 8$ & 161 & -48 & 40 & 3 & 127 & $27 \mathrm{~N}$ & 178 & -30 \\
\hline 63 & $42^{\circ} 39^{\prime} 8^{\prime \prime} \mathrm{N}$ & $0^{\circ} 4^{\prime} 11^{\prime \prime} \mathrm{E}$ & AÑI-6 & $8 / 10$ & 186 & -38 & 13 & 17 & 100 & $12 \mathrm{~S}$ & 185 & -60 \\
\hline 64 & $42^{\circ} 39^{\prime} 2^{\prime \prime} \mathrm{N}$ & $0^{\circ} 4^{\prime} 7^{\prime \prime} .6 \mathrm{E}$ & AÑI-7 & $14 / 20$ & 179 & -61 & 6 & 49 & 98 & $47 \mathrm{~S}$ & 23 & -72 \\
\hline 65 & $42^{\circ} 38^{\prime} 54^{\prime \prime} .4 \mathrm{~N}$ & $0^{\circ} 4^{\prime} 5^{\prime \prime} .4 \mathrm{E}$ & AÑI-8 & $9 / 10$ & 168 & -16 & 10 & - & 104 & $18 \mathrm{~S}$ & 164 & -34 \\
\hline 66 & $42^{\circ} 38^{\prime} 54^{\prime \prime} .4 \mathrm{~N}$ & $0^{\circ} 4^{\prime} 0^{\prime \prime} \mathrm{E}$ & AÑI-9 & - & - & - & - & - & 120 & $18 \mathrm{~S}$ & - & - \\
\hline 67 & $42^{\circ} 38^{\prime} 46^{\prime \prime} .4 \mathrm{~N}$ & $0^{\circ} 4^{\prime} 0^{\prime \prime} \mathrm{E}$ & AÑI-10 & $9 / 10$ & 166 & -52 & 15 & - & 108 & $3 \mathrm{~S}$ & 142 & -62 \\
\hline 68 & $42^{\circ} 41^{\prime} 28^{\prime \prime} .8 \mathrm{~N}$ & $0^{\circ} 2^{\prime} 22^{\prime \prime} \mathrm{E}$ & MAR-1 & $4 / 8$ & 164 & -36 & 20 & 17 & 100 & $10 \mathrm{~S}$ & 160 & -45 \\
\hline 69 & $42^{\circ} 41^{\prime} 16^{\prime \prime} \mathrm{N}$ & $0^{\circ} 2^{\prime} 41^{\prime \prime} .8 \mathrm{E}$ & MAR-2 & $7 / 10$ & 178 & -42 & 10 & 25 & 124 & $17 \mathrm{~S}$ & 165 & -55 \\
\hline 76 & $42^{\circ} 35^{\prime} 20^{\prime \prime} \mathrm{N}$ & $0^{\circ} 13^{\prime} 53^{\prime \prime} .6 \mathrm{E}$ & CIN-2 & $3 / 5$ & 164 & -43 & 33 & 10 & 88 & $38 \mathrm{~S}$ & 126 & -77 \\
\hline 78 & $42^{\circ} 34^{\prime} 44^{\prime \prime} \mathrm{N}$ & $0^{\circ} 18^{\prime} 26^{\prime \prime} .4 \mathrm{~W}$ & QIN-2 & $8 / 10$ & 153 & -67 & 9 & 35 & 10 & $45 \mathrm{~W}$ & 121 & -29 \\
\hline \multicolumn{13}{|c|}{ Hecho Group (Eocene) } \\
\hline 79 & $42^{\circ} 39^{\prime} 29^{\prime \prime} .7 \mathrm{~N}$ & $0^{\circ} 19^{\prime} 14^{\prime \prime} .5 \mathrm{~W}$ & ELE-4 & $5 / 8$ & 216 & -22 & 22 & 10 & 68 & $29 \mathrm{~S}$ & 230 & -34 \\
\hline 80 & $42^{\circ} 39^{\prime} 29^{\prime \prime} .4 \mathrm{~N}$ & $0^{\circ} 19^{\prime} 14^{\prime \prime} .5 \mathrm{~W}$ & ELE-5 & $8 / 11$ & 209 & -40 & 13 & 16 & 104 & $84 \mathrm{~S}$ & 352 & -53 \\
\hline 81 & $42^{\circ} 37^{\prime} 58^{\prime \prime} .4 \mathrm{~N}$ & $0^{\circ} 19^{\prime} 36^{\prime \prime} .5 \mathrm{~W}$ & ELE-6 6 & $8 / 10$ & 225 & -32 & 19 & 8 & 77 & $86 \mathrm{~N}(\mathrm{i})$ & 295 & -24 \\
\hline 82 & $42^{\circ} 37^{\prime} 58^{\prime \prime} .4 \mathrm{~N}$ & $0^{\circ} 19^{\prime} 36^{\prime \prime} .5 \mathrm{~W}$ & ELE-7 & $7 / 9$ & 205 & -24 & 15 & 15 & 153 & $20 \mathrm{~N}$ & 208 & -8 \\
\hline 83 & $42^{\circ} 35^{\prime} 48^{\prime \prime} \mathrm{N}$ & $0^{\circ} 18^{\prime} 8^{\prime \prime} .5 \mathrm{~W}$ & ELE-8 & $5 / 8$ & 200 & -27 & 24 & 9 & 65 & $35 \mathrm{~S}$ & 223 & -48 \\
\hline 84 & $42^{\circ} 35^{\prime} 48^{\prime \prime} \mathrm{N}$ & $0^{\circ} 18^{\prime} 8^{\prime \prime} .5 \mathrm{~W}$ & ELE-9 & - & - & - & - & - & 108 & $64 \mathrm{~N}(\mathrm{i})$ & - & - \\
\hline 85 & $42^{\circ} 34^{\prime} 31^{\prime \prime} .2 \mathrm{~N}$ & $0^{\circ} 17^{\prime} 35^{\prime \prime} .5 \mathrm{~W}$ & ELE-10 & $5 / 7$ & 180 & -53 & 18 & 16 & 60 & $15 \mathrm{~S}$ & 196 & -65 \\
\hline 86 & $42^{\circ} 33^{\prime} 29^{\prime \prime} \mathrm{N}$ & $0^{\circ} 21^{\prime} 4^{\prime \prime} .5 \mathrm{~W}$ & ELE-11 & - & - & - & - & - & 110 & $65 \mathrm{~N}(\mathrm{i})$ & - & - \\
\hline 87 & $42^{\circ} 33^{\prime} 29^{\prime \prime} \mathrm{N}$ & $0^{\circ} 21^{\prime} 4^{\prime \prime} .5 \mathrm{~W}$ & ELE-12 & - & - & - & - & - & 14 & $13 \mathrm{E}$ & - & - \\
\hline
\end{tabular}

${ }^{\mathrm{a}}$ Latitude; longitude; $\mathrm{n} / \mathrm{N}$, number of samples over the total per site; $\mathrm{D}$, declination; I, inclination; $\alpha_{95}$ and $\mathrm{k}$, statistical parameters associated with the means; So, bed (strike and dip); (i), overturned; BTC, before tectonic correction; and ATC, after tectonic correction.

this case, is not statistically distinguishable from the Cretaceous reference (D/I of 002/44; $\left.\alpha_{95}=7 ; \mathrm{k}=94\right)$.

[32] Because of the fact that the B component shows a distinguishable clockwise rotation respect to the Tertiary reference and in addition to that, the $\mathrm{B}$ component is present in almost all sites, we focus on the rotation of the $B$ component in six different sectors along the IS. Every regional sector will provide a rotation value for a segment of the IS (Figure 10 and Table 3). It can be seeing that a more homogeneous rotation is documented in the western part (sectors 1 to 3 ), ranging from $+11^{\circ}$ to $+16^{\circ}$. The clockwise rotation reaches its maximum with $+26^{\circ}$ in sector 4. Toward the east, sector 5 shows few sites that carry the secondary component, so the errors of the mean direction are slightly higher. Notice that the anticlockwise rotation found in sector 5 is out of the regional trend of clockwise rotations but is also not significant; there is an overlapping of sector 5 mean and the reference direction confidence cone. Finally, sector 6 outlines the results from the Eocene deposits in the Jaca-Pamplona turbiditic basin. The rotation in the turbiditic basin also shows a clockwise rotation of $+22^{\circ}$ that follows the regional trend found in the Internal Sierras.
[33] This clockwise rotation registered in an E-W trending and fairly straight structural zone accounts for the differential shortening along strike that is deduced from balanced cross sections [Choukroune and ECORS Team, 1990; Muñoz, 1992; Martínez-Peña and Casas-Sainz, 2003]. The higher shortening value in the southwestern Pyrenees is recorded to the east in the Cotiella-Neste Aure section with $88 \mathrm{~km}$ [Martinez-Peña and Casas-Sainz, 2003], whereas the lower value with $26 \mathrm{~km}$ is recorded to the west (Ansó-Arzacq section by Teixell [1992]). Since rotations $(\beta)$ and differential shortening $(\Delta S)$ are mathematically related, we can use this function to calculate the expected rotation value from the shortening differences in the boundaries of the studied area: $\Delta \mathrm{S}=\mathrm{Sc}_{1}-\mathrm{Sc}_{2}=2 \mathrm{D}$ $\sin (\beta / 2)$ and then $\beta=2 \arcsin (\Delta \mathrm{S} / 2 \mathrm{D})$ [Pueyo et al., 2004; A. Sussman et al., The impact of vertical-axis rotations on shortening estimates, submitted to Journal of Structural Geology, 2007, hereinafter referred to as Sussman et al., submitted manuscript, 2007], where Sc1 is the shortening in the west, the $\mathrm{Sc} 2$ is the shortening in the east, $\mathrm{D}$ is the distance between the two sections $(100 \mathrm{~km})$, and $\beta$ is the rotation value. The expected rotation in the IS is $\beta=+11^{\circ}$, which is the same order of magnitude that we obtain with 
Table 1b. Paleomagnetic Data of the C Component $\mathrm{t}^{\mathrm{a}}$

\begin{tabular}{|c|c|c|c|c|c|c|c|c|c|c|}
\hline \multirow[b]{2}{*}{ Site Number } & \multirow[b]{2}{*}{ Site Name } & \multirow[b]{2}{*}{$\mathrm{n} / \mathrm{N}$} & \multicolumn{4}{|c|}{ "In Situ" BTC } & \multicolumn{4}{|c|}{ ATC } \\
\hline & & & $\mathrm{D}$ & I & $\alpha_{95}$ & $\mathrm{k}$ & So Strike & So Dip & $\mathrm{D}$ & I \\
\hline \multicolumn{11}{|c|}{ Calcaires des Cañons } \\
\hline 13 & ARA-5 & $6 / 9$ & 25 & 31 & 7 & 13 & 114 & $20 \mathrm{~S}$ & 25 & 51 \\
\hline 30 & PIE-3 & $26 / 55$ & 14 & 43 & 6 & 21 & 87 & $45 \mathrm{~S}$ & 84 & 77 \\
\hline 34 & ELE-1 & $6 / 13$ & 355 & -1 & 7 & 74 & 88 & $59 \mathrm{~S}$ & 352 & 58 \\
\hline 38 & ASN-3 & $9 / 10$ & 189 & 24 & 11 & 19 & 96 & $45 \mathrm{~S}$ & 189 & -26 \\
\hline 41 & TEN-3 & $5 / 9$ & 339 & -15 & 8 & 71 & 74 & $65 \mathrm{~S}$ & 336 & 50 \\
\hline 43 & OTA-2 & $20 / 45$ & 350 & 45 & 9 & 14 & 82 & $44 \mathrm{~S}$ & 301 & 88 \\
\hline 47 & OTA-6 & $16 / 23$ & 207 & 46 & 11 & 13 & 118 & $68 \mathrm{~N}(\mathrm{i})$ & 206 & -66 \\
\hline 70 & PIN-1 & $13 / 20$ & 37 & 32 & 11 & 14 & 134 & $36 \mathrm{~S}$ & 29 & 67 \\
\hline \multicolumn{11}{|c|}{ Zuriza Marls Formation } \\
\hline 10 & TOR-2 & $17 / 25$ & 18 & 22 & 5 & 41 & 110 & $22 \mathrm{~N}$ & 18 & 0 \\
\hline 21 & IP-1 & $7 / 10$ & 19 & 28 & 12 & 25 & 125 & $43 \mathrm{~S}$ & 355 & 67 \\
\hline 108 & MG-2 & $10 / 10$ & 189 & 18 & 10 & 25 & 114 & $60 \mathrm{~S}$ & 185 & -40 \\
\hline \multicolumn{11}{|c|}{ Marboré Sandstones Formation } \\
\hline 4 & ARG-4 & $8 / 12$ & 23 & 34 & 9 & 63 & 40 & $12 \mathrm{~N}$ & 16 & 30 \\
\hline 6 & ARG-6 & $8 / 10$ & 352 & 28 & 15 & 13 & 155 & $25 \mathrm{~W}$ & 338 & 32 \\
\hline 7 & ARG-7 & $13 / 15$ & 18 & 26 & 7 & 21 & 140 & $18 \mathrm{~S}$ & 11 & 41 \\
\hline 8 & ARG-8 & $21 / 26$ & 17 & 39 & 5 & 46 & 115 & $25 \mathrm{~S}$ & 11 & 64 \\
\hline 15 & ARA-7 & $9 / 10$ & 13 & 28 & 9 & 34 & 147 & $10 \mathrm{~W}$ & 8 & 35 \\
\hline 16 & ARA-8 & $9 / 9$ & 17 & 24 & 10 & 24 & 110 & $25 \mathrm{~S}$ & 16 & 49 \\
\hline 17 & AGU-1 & $33 / 36$ & 32 & 47 & 5 & 24 & 40 & $15 \mathrm{~W}$ & 17 & 43 \\
\hline 18 & AGU-2 & $9 / 10$ & 21 & 34 & 7 & 56 & 10 & $26 \mathrm{~W}$ & 3 & 35 \\
\hline 23 & COL-1 & $8 / 10$ & 359 & 19 & 8 & 45 & 104 & $13 \mathrm{~N}$ & 360 & 7 \\
\hline 25 & ACU-1 & $10 / 10$ & 356 & -38 & 6 & 64 & 88 & $78 \mathrm{~S}$ & 356 & 40 \\
\hline 26 & ACU-2 & $8 / 10$ & 1 & 42 & 7 & 51 & 88 & $4 \mathrm{~N}$ & 1 & 38 \\
\hline 29 & PIE-4 & $16 / 30$ & 10 & 63 & 7 & 29 & 3 & $35 \mathrm{~S}$ & 54 & 44 \\
\hline 35 & ELE-2 & $16 / 45$ & 358 & -20 & 7 & 27 & 150 & $63 \mathrm{~S}$ & 2 & 14 \\
\hline 40 & TEN-2 & $12 / 30$ & 165 & 22 & 12 & 13 & 90 & $57 \mathrm{~S}$ & 164 & -33 \\
\hline 54 & TAI-1 & $14 / 25$ & 19 & 43 & 16 & 6 & 70 & $55 \mathrm{~S}$ & 98 & 59 \\
\hline 62 & AÑI-5 & $28 / 54$ & 9 & 59 & 5 & 31 & 127 & $27 \mathrm{~N}$ & 20 & 34 \\
\hline 65 & AÑI-8 & $16 / 24$ & 10 & 32 & 9 & 18 & 104 & $18 \mathrm{~S}$ & 8 & 50 \\
\hline 69 & MAR-2 & $11 / 24$ & 13 & 24 & 9 & 23 & 124 & $17 \mathrm{~S}$ & 9 & 40 \\
\hline 111 & ARA-1 & $10 / 10$ & 36 & 43 & 9 & 44 & 62 & $16 \mathrm{~N}$ & 25 & 35 \\
\hline 112 & ARA-2 & $10 / 10$ & 22 & 26 & 6 & 61 & 46 & $13 \mathrm{~S}$ & 21 & 33 \\
\hline 113 & GAL-1 & $8 / 10$ & 188 & 15 & 17 & 19 & 94 & $46 \mathrm{~S}$ & 189 & -31 \\
\hline
\end{tabular}

${ }^{a}$ Legend as in Table 1a.

the paleomagnetic analysis from the mean of the B component $\left(+13^{\circ}\right)$. The expected value of the rotation is also close to the value of the statistically insignificant rotation of the mean of the $\mathrm{C}$ component $\left(+8^{\circ}\right)$. The calculation of the rotation allows correcting the effect of out-of-plane movement within cross sections, which causes errors on the traditional shortening estimation [Pueyo et al., 2004; Oliva-Urcia and Pueyo, 2005; Sussman et al., submitted manuscript, 2007].

[34] Higher rotation values have been found in the External Sierras and the Jaca-Pamplona Basin [Pueyo, 2000; Pueyo et al., 2002, 2003a, 2003b] and in the Aínsa Basin, which is situated to the west of the SPCU [Fernández et al., 2003; Fernández, 2004; Muñoz et al., 2003]. However these values are partially related to the development of certain large-scale oblique structures (Boltaña anticline) that accommodate strong local gradients of shortening. In any case, the value detected in the IS as well as in the frontal portions of the ES can be related to the orogenic-scale gradient of shortening detected in the southwestern Pyrenees by cross section balancing although the causal origin remains unclear.

[35] In order to clarify the relationship between the rotation of both components (B and $\mathrm{C}$ ), we focus now on the sites where both the remagnetization and the primary component have been isolated (around 30\% of the total data set). The rotation registered by the $\mathrm{B}$ component in each site is subtracted from the declination of the $\mathrm{C}$ component of the same site, so that we can calculate the orientation of the $\mathrm{C}$ component before the rotation of the $\mathrm{B}$ component takes place, or in other words, at the time the B component is blocked within the rocks. Besides, this operation may help to find some clues about the age of the rotation of the remagnetization component. As shown in Figure 11, the position of the mean of the $\mathrm{C}$ component prior to the rotation of $\mathrm{B}$ component and at the time of the remagnetization (D/I of $\left.001 / 49 ; \alpha_{95}=10 ; \mathrm{k}=8\right)$, is statistically indistinguishable from the Upper Cretaceous reference (D/I 


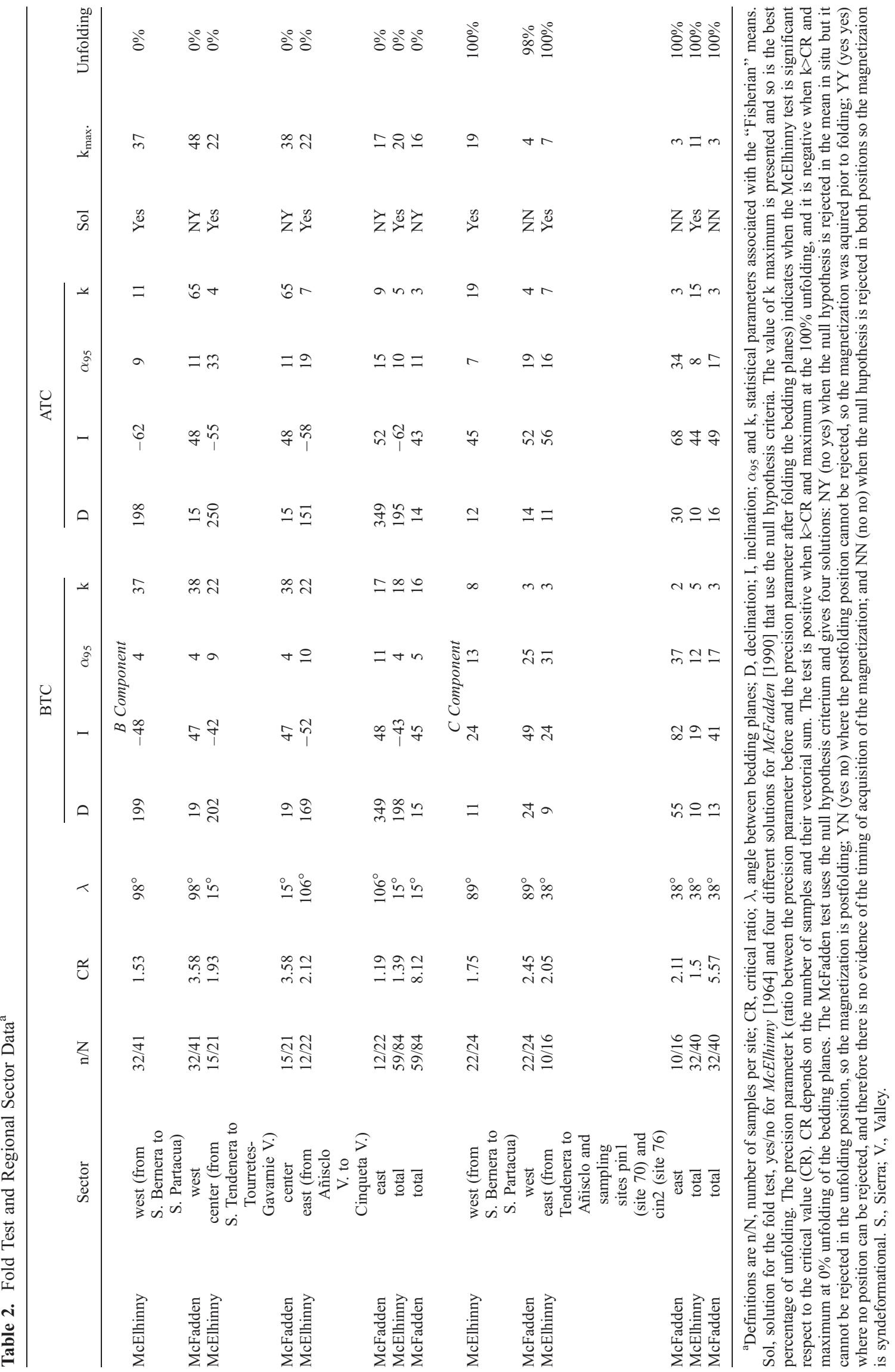




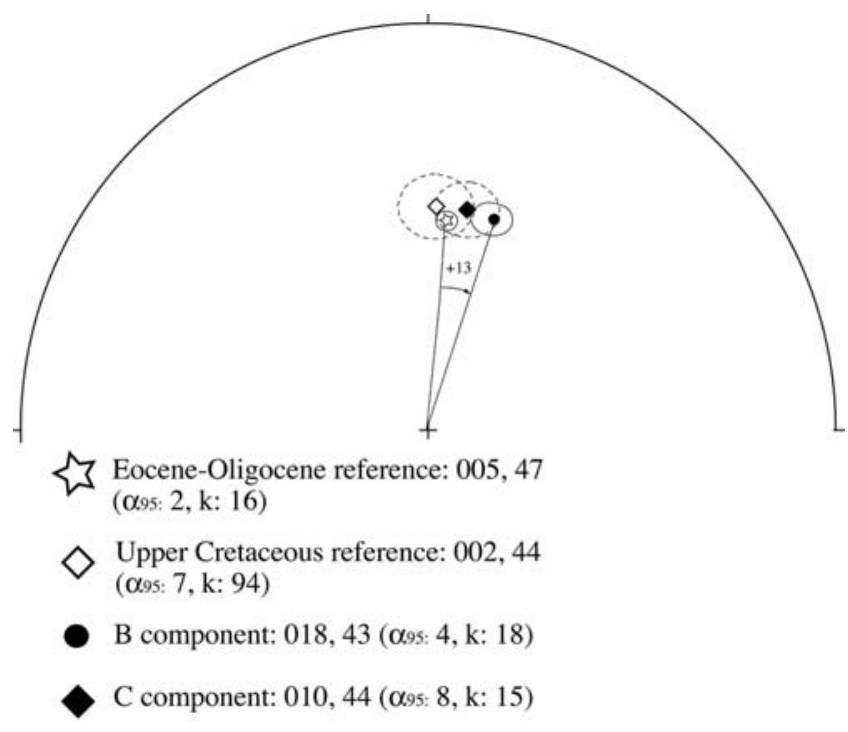

Figure 9. Lower hemisphere stereograph with mean values of Upper Cretaceous and Eocene rocks of B and C components.

of $\left.002 / 44, \alpha_{95}=7 ; \mathrm{k}=94\right)$. Therefore there is neither previous nor statistically significant rotational event in this area of the Pyrenees before the rotation registered by the B component takes place. The dating of the remagnetization component is of key importance to assign a date to the rotation event in the Pyrenees, as it will be shown later.

\subsection{Coupling Between Cover and Basement Thrusts}

[36] The structure in the western part of the studied area allows characterizing the relationship between cover and basement thrust systems. In the west of the IS between the Aragón-Subordán river and the Gállego river (see Foldout 1 for location), two groups of sites are split. In that sector, the cover of the Upper Cretaceous rocks unconformably overlies the Paleozoic of the axial zone, but higher in the section the Upper Cretaceous rocks are also affected by the LarraMonte Perdido thrust system. The two groups of sites are as follows: (1) The first group is located in the sediments overlain the Paleozoic rocks, which implies that the materials are affected by the Gavarnie and the Guarga basement thrusts. (2) The second group gathers sites higher in the section, affected by both the basement thrusts mentioned above and also the previous cover thrusts (the Larra-Monte Perdido imbricated thrust system).

[37] The results show that the B component is indistinguishable between group 1 and group 2 (Figure 12). The group of sites from the overlain cover of Paleozoic basement rocks (group 1) shows a mean of D/I $\mathrm{I}_{1}$ of 203/-46 ( $\alpha_{95}$ $=7, \mathrm{k}=24$ ) from 18 sites, while the second group reveals a mean of $\mathrm{D} / \mathrm{I}_{2}$ of $199 /-45\left(\alpha_{95}=5, \mathrm{k}=62\right)$ from 15 sites. The first and interesting deduction we obtain from the overlapping of the paleomagnetic directions of the two groups is that the cover thrust system (Larra-Monte Perdido) does not produce any significant rotation in the area. Secondly, the B component is clearly affected by a clock- wise rotation (between +14 and +18 ) with respect to the Tertiary reference.

\subsection{Other Timing Considerations About the Remagnetization Event}

[38] On one hand, the younger sediments with the $\mathrm{B}$ component are the Eocene turbidites. Because the B component is postfolding, this implies that the remagnetization event takes place after the folding of those materials. The folding of the turbidites occurs sometime between the middle and upper Eocene, when the Larra-Monte Perdido, Gavarnie, and Bielsa thrust sheets deform the flysch deposits [Labaume et al. 1985; Teixell, 1992, 1996; MartínezPeña and Casas-Sainz, 2003]. On the other hand, the comparison of the inclination of the $\mathrm{B}$ component respect to the inclination of the Tertiary reference will give more information about the timing of the remagnetization. The $\mathrm{B}$ component is not affected by the tilting of the basement thrusts that incline the Mesozoic-Tertiary cover near the axial zone. This suggests that the B component is acquired after the first stages of the movement of the Gavarnie (in the western part) and the Bielsa (in the eastern part) thrusts. This is represented in Figure 13, where a geological cross section from the western part shows also the mean of the B component in each thrust sheet. The inclination of the B component in each thrusts sheet is similar to the Tertiary reference in spite of the tilting found in Upper Cretaceous rocks affected by the Gavarnie thrust. Therefore the remagnetization is postbasement stacking and hence gives highly kinematic information: the rotation of the $\mathrm{B}$ component is also younger than the stacking basement thrust sheets (Bielsa and Gavarnie).

[39] Apart from that, the reverse polarity found in all sites for the $\mathrm{B}$ component indicates that the remagnetization event blocks the component during, most probably, a sole reverse polarity chron which are not longer that $4 \mathrm{Ma}$ in Cretaceous-Tertiary times.

\subsection{Remagnetization}

[40] It is known that different causes can produce remagnetizations in carbonates, but due to the geological characteristics of the Internal Sierras, the following remagnetization mechanism did not take place in the studied area: (1) thermoremanent magnetization (TRM) because the IS have never been affected by a high metamorphic event, as in the northern side of the axial zone [Albarède and VitracMichard, 1978; Mattauer, 1985; Montigny et al., 1986], and lower metamorphic grade temperatures would have needed hundreds of millions of years to reset the previous magnetic carriers present in the sediments (following Pullaiah et al. [1975]), (2) chemical remanent magnetization (CRM) attributed to burial diagenesis or organic mater maturation, because it would produce a prefolding remagnetization component and neither account for the different types of rocks nor for the different tectonosedimentary settings and their geochemical evolution that occur in the IS, and (3) CRM (and partial TRM) due to orogenic fluids. Orogenic fluids are not taking into account because chemical studies in fluids inclusions in the region [Travé et al., 

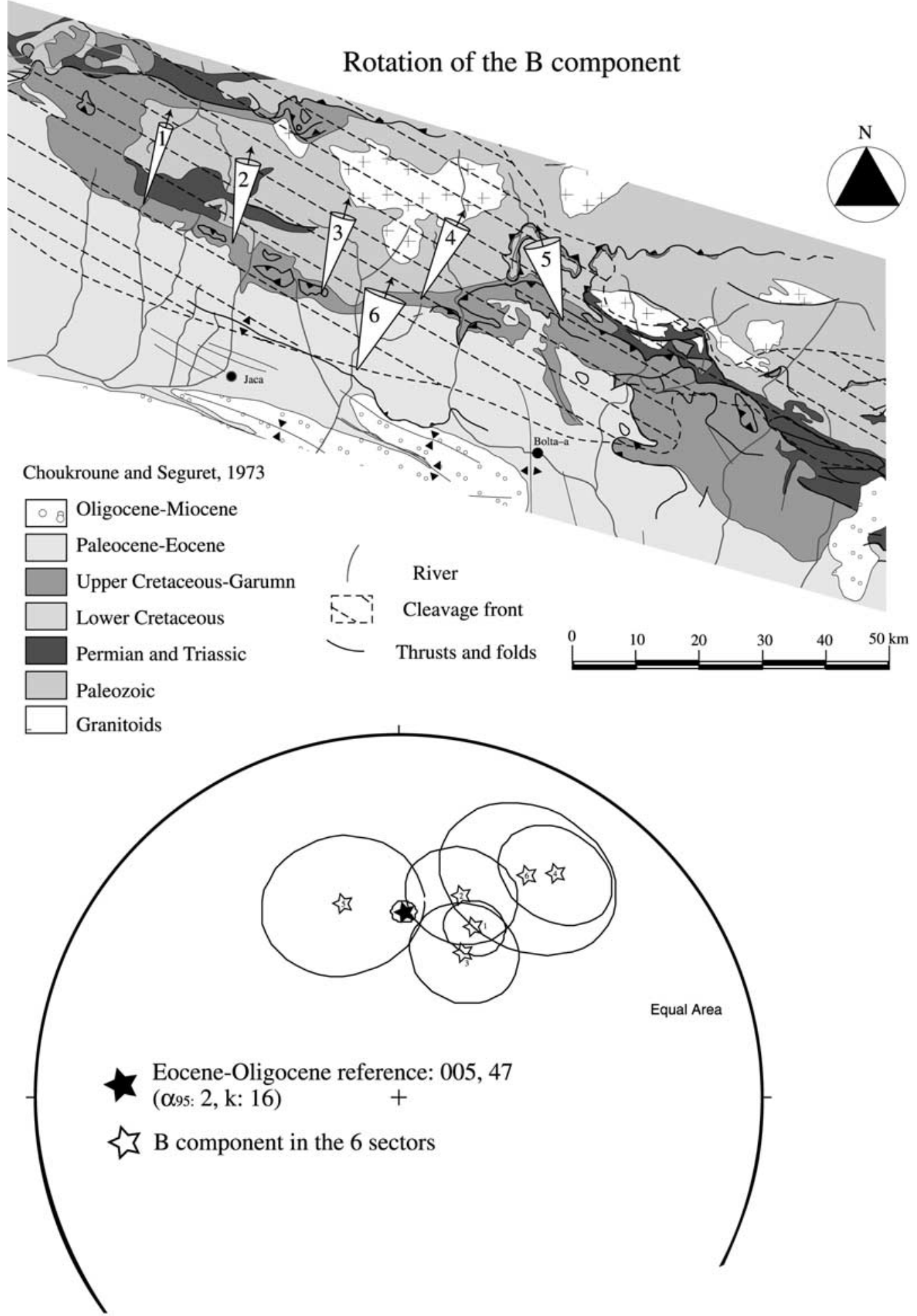

Figure 10. Map view and stereographic projection of the mean rotation of the $B$ component in each sector with the cones showing the $\alpha_{95}$. The Tertiary reference is also plotted in the lower hemisphere. 
Table 3. Data for Each of the Six Regional Sectors ${ }^{\mathrm{a}}$

\begin{tabular}{|c|c|c|c|c|c|c|c|c|c|c|c|c|c|}
\hline \multirow[b]{2}{*}{ Sector } & \multirow[b]{2}{*}{$\mathrm{n} / \mathrm{N}$} & \multirow[b]{2}{*}{$\mathrm{CR}$} & \multirow[b]{2}{*}{ Minimum $\lambda$} & \multicolumn{4}{|c|}{ In Situ BTC } & \multicolumn{4}{|c|}{ Corrected ATC } & \multirow[b]{2}{*}{ Aboslute $\gamma$} & \multirow[b]{2}{*}{$\operatorname{Ref}(005,47) \gamma^{\mathrm{b}}$} \\
\hline & & & & $\mathrm{D}$ & I & $\alpha_{95}$ & $\mathrm{k}$ & $\mathrm{D}$ & I & $\alpha_{95}$ & $\mathrm{k}$ & & \\
\hline Sierra Bernera & $12 / 14$ & 2.22 & 102 & 201 & -47 & 5 & 75 & 194 & -63 & 12 & 14 & +21 & +16 \\
\hline $\begin{array}{l}\text { Sierra Aísa and } \\
\text { River Aragón }\end{array}$ & $9 / 12$ & 2.32 & 104 & 196 & -42 & 9 & 30 & 186 & -51 & 19 & 7 & +16 & +11 \\
\hline $\begin{array}{l}\text { Sierra Collarada and } \\
\text { Sierra Partacua }\end{array}$ & $11 / 18$ & 2.12 & 98 & 201 & -52 & 9 & 26 & 228 & -72 & 19 & 7 & +21 & +16 \\
\hline $\begin{array}{l}\text { Sierra Tendenera and } \\
\text { Valley Otal }\end{array}$ & $10 / 15$ & 2.61 & 38 & 211 & -31 & 9 & 34 & 255 & -54 & 37 & 3 & +31 & +26 \\
\hline $\begin{array}{l}\text { Tourretes Valley and } \\
\text { Añisclo Valley and } \\
\text { MAR sites in Lago } \\
\text { Helado de Marboré }\end{array}$ & $7 / 20$ & 1.99 & 15 & 170 & -45 & 13 & 18 & 236 & -57 & 97 & 2 & -10 & -15 \\
\hline Flysch & $6 / 9$ & 2.69 & 30 & 207 & -34 & 14 & 20 & 243 & -51 & 42 & 4 & +27 & +22 \\
\hline
\end{tabular}

${ }^{a}$ Definitions are $\mathrm{n} / \mathrm{N}$, number of samples per site; $\mathrm{CR}$, critical ratio; $\lambda$, angle between bedding planes; $\mathrm{D}$, declination; I, inclination; $\alpha_{95}$ and $\mathrm{k}$, statistical parameters associated with the "Fisherian" means; and $\gamma$, the rotation (both absolute and referring to the Eocene-Oligocene reference).

${ }^{\mathrm{b}}$ Paleomagnetic reference for rotations in Tertiary (Eocene-Oligocene).

1997; McCaig et al., 2000] suggest large difference in the chemistry of the brines running through the major thrusts in the southwestern Pyrenees. In that case, different ferromagnetic minerals would be expected. Besides, the dominant flow might be conducted by thrusts planes and it may not affect the whole sequence of sediments, as it has been previously pointed out [Elmore et al., 2001] so a widespread remagnetization would not be the case, as it occurs in the Internal Sierras.

[41] Looking at the distribution of remagnetized and nonremagnetized sites, and the location of the cleavage domain; it is remarkable that all sites with a postfolding remagnetization are in the pressure solution cleavage domain. Because of this fact, we suggest that the remagnetization event in the Internal Sierras takes place during the alpine evolution of the mountain range when the main regional cleavage domain develops. That means there is not only a spatial relationship between the cleavage domain and the remagnetization but also a link in time and origin. The proposed mechanism is as follows: during the development of the pressure solution type of cleavage, the carbonatic matrix dissolves, and the ferrimagnetic minerals, which are part of the non soluble fraction, are left behind and reorient with the new magnetic field in the cleavage planes [Oliva-Urcia, 2003]. With the available data we cannot discard that neocrystallization of magnetite related to the pressure solution cleavage can take place, as it has been suggested for remagnetization events in weakly deformed mud rocks [Housen et al., 1993] and limestones [Lewchuk et al., 2003; Evans and Elmore, 2006]. Besides, the low-temperature analyses (Figure 5) may indicate the presence of SP magnetite grains [Xu et al., 1998; Katz et al., 1998], although they can also indicate the presence of goethite (see Weil and Van der Voo [2002] after Özdemir and Dunlop [2000]). The presence of SP grains would indicate a chemical remagnetization origin. Analysis and observations using scanning electron microscopy (SEM) will provide some light on this specific subject, which is beyond the scope of the paper.

[42] In order to discuss the age of the cleavage domain we address some constrains to the development of pressure solution type of cleavage in the area:

[43] It is suggested from chemical analysis in fluid inclusions and from structural analysis that the overburden on top of the volume of rocks that develops the cleavage planes in the studied area is about $4-7 \mathrm{~km}$. To reach such

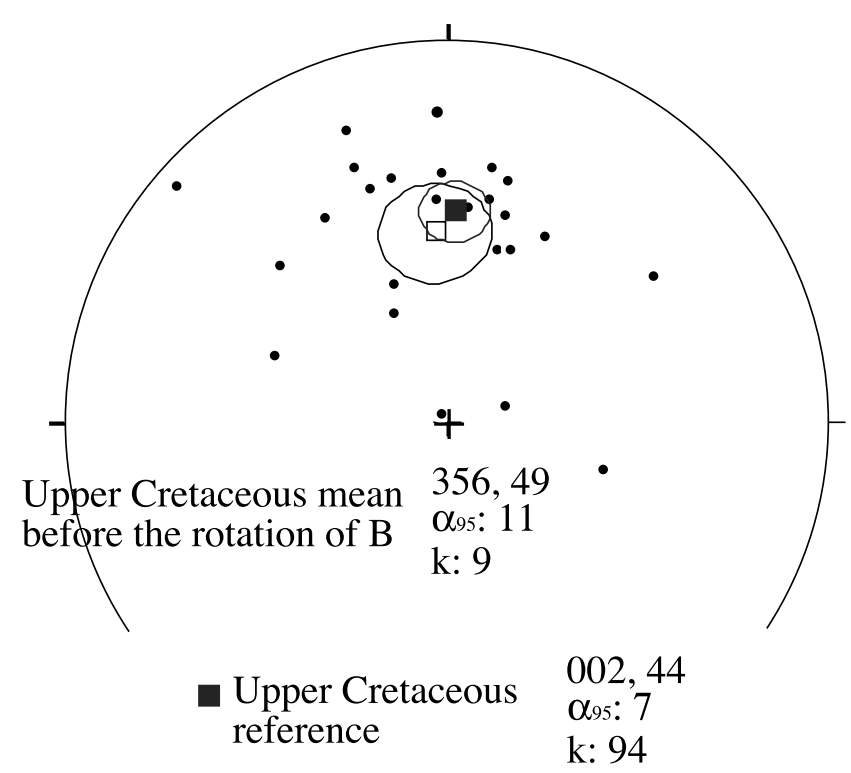

Figure 11. $\mathrm{C}$ component at the moment of the remagnetization: dec $\mathrm{C}$ (in each site) minus rotation of $\mathrm{B}$ (in the correspondent site). The error cone of the new distribution of the $\mathrm{C}$ component at this time overlaps with the cone of the Upper Cretaceous reference. 


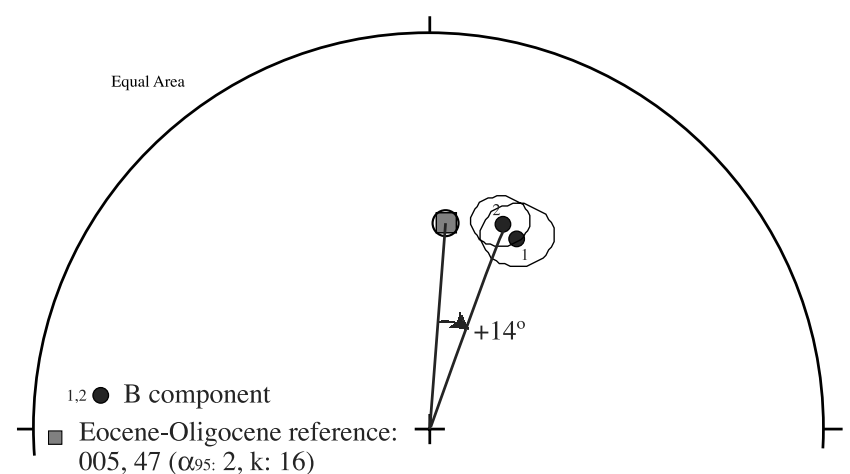

Figure 12. Equal-area projection in lower hemisphere. The B component (dots) of both groups is indistinguishable but is clearly different from the Eocene reference.

pile of sediments on top of the turbiditic basin, younger sediments of Bartonian-Rupelian age will deposit. The sediments comprise platform, transitional and continental environments related to the filling of the foreland basin during the tectonic compression. Therefore the age of the deposition of these sediments and the beginning of their exhumation constrain the time when the cleavage develops. In other words, the beginning of the exhumation and erosion of the sedimentary pile restricts the developing age of the regional cleavage domain. The early start of the exhumation takes place when Guarga thrust sheet emplaces in the west side, so that the cleavage development cannot be later than the base of the Chattian (Oligocene). Therefore we propose that the development of the wide- spread remagnetization event may occur at around $30 \mathrm{Ma}$ ago (Rupelian), and possibly during the chron $\mathrm{C} 12 \mathrm{R}$, which is the longest reversal polarity chron (around $2 \mathrm{Ma}$ according to Cande and Kent [1995]).

\section{Conclusions}

[44] The paleomagnetic data presented here allow us to distinguish two stable magnetization components in the Upper Cretaceous sediments: (1) the intermediate component (B) that unblocks between $300^{\circ} \mathrm{C}$ and $450^{\circ} \mathrm{C}$, is always reverse and postfolding, and shows a total mean rotation of $+13^{\circ}$; and (2) the $\mathrm{C}$ component with higher unblocking temperature (between $500^{\circ} \mathrm{C}$ and $580^{\circ} \mathrm{C}$ ) that has two polarities, is prefolding and shows a total mean rotation of $+8^{\circ}$, although is not statistically significant. The turbiditic deposits also show the presence of the same $\mathrm{B}$ component and in two samples the $\mathrm{C}$ component was described. The main carrier of the magnetization is magnetite (shown by the unblocking temperatures and the Verwey transition in low-temperature curves). Small contributions of hard coercivity ferromagnetic minerals (goethite, hematite) can be present too.

[45] The kinematics deductions derived from both components are the followings: There is not differential rotation between the cover and the basement thrust systems in the area during the first stage of the evolution of the orogen (following Storti et al. [2000]). Besides, there are not significant rotations before the acquisition of the remagnetization component. On the contrary, the second evolution stage of the orogen (emplacement of Guarga basement thrust) produces a moderate clockwise rotation in the internal parts of the chain (Internal Sierras) of around $+13^{\circ}$ regarding the mean of the $\mathrm{B}$ component. This rotation

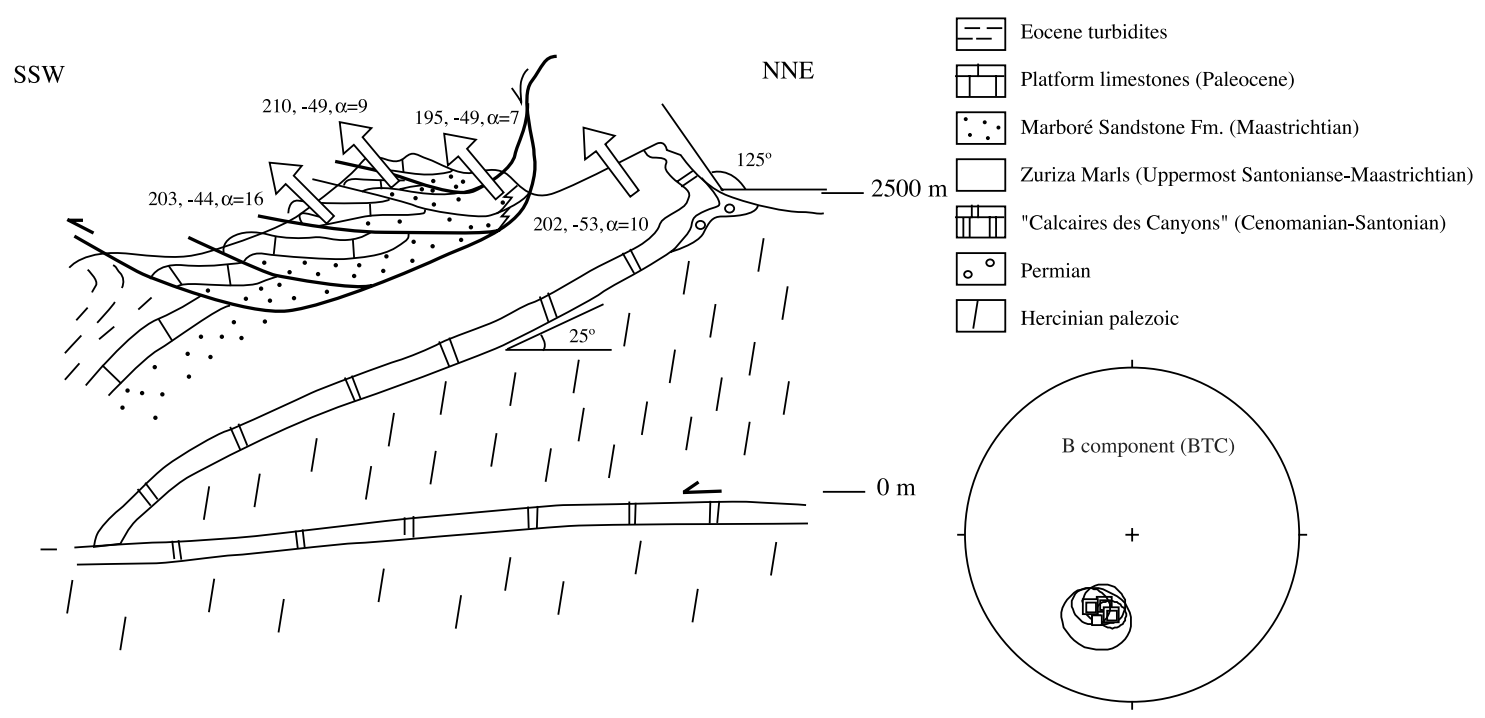

Figure 13. Sierra Bernera cross section [from Teixell, 1992] in the western part of the drilled area. The vectors indicate the mean of the $\mathrm{B}$ component in each thrust sheet (three to five sites were used to calculate the mean in each thrust sheet). 
affects both the cover (Larra-Monte Perdido thrust) and the basement (Gavarnie, Milares, Bielsa) thrusts systems. The rotation accounts for the differential shortening along the strike at orogenic scale (southwestern Pyrenees) as can be deduced from balanced cross sections [Teixell, 1998; Martinez-Peña and Casas-Sainz, 2003]. In the external parts of the orogen (External Sierras or in the Aínsa Basin) the rotation associated with the latest basement thrust emplacement (Guarga) shows similar results but can be higher (up to $+45^{\circ}$ or more) in some local structures (Pico del Águila or Boltaña anticlines in the ES [Pueyo, 2000; Fernández, 2004]).

[46] Our data together with previous paleomagnetic data suggest the spatial and causal relationship of the remagnetization component with the main cleavage development in the Internal Sierras. The remagnetization event occurs later than the folding of the Flysch sediments (middle-upper Eocene), which are the younger rocks showing the presence of this postfolding component. The age of the remagnetiza- tion is also constrained by the inclination of the B component, which shows that is not affected by the stacking of the basement thrusts (Gavarnie, Bielsa), so it is also later than the beginning of the emplacement of those basement thrusts (later than Priabonian-upper Eocene).

[47] Acknowledgments. B. Oliva thanks a grant to the Diputación General de Aragón and a postdoctoral scholarship from MEC. E. Pueyo was funded by a FWF (Austrian Science Fundings) and a Ramón y Cajal Young Research Contract (MEC). Other funding comes from the projects BTE 2002-04168, CGL2006-2289-BTE (MEC), and Geokin3DPyr (CTPR04/2005-INTERREG IIIa-European Council). We thank people assisting in the field. Analyses were possible thanks to the laboratories of Barcelona (Institute Jaume Almera-Universitat de Barcelona) and Gams (Leoben Montauniversitët), where useful discussions with Miguel Garcés, Bet Beamud, Robert Scholger, and Herman Mauristchs helped to further interpretation of data. We thank the Institute for Rock Magnetism, especially Mike Jackson, and the National Science Foundation for the rock magnetism analysis. Thank you also to Arlo Weil and one anonymous reviewer; their comments helped to improve the manuscript.

\section{References}

Albarède, F., and A. Vitrac-Michard (1978), Datation du métamorphisme des terrains secondaires des Pyrénées par la methode ${ }^{39} \mathrm{Ar}-{ }^{40} \mathrm{Ar}$ et ${ }^{37} \mathrm{Rb}-{ }^{87} \mathrm{Sr}$, ses relations avec les péridotites associés, Bull. Soc. Geol. Fr., 7, 681-687.

Almar, Y., E. Beamud, M. Garces, X. Murelaga, J. A. Muñoz, and L. Cabrera (2004), Magnetostratigraphic record of the syntectonic infill in the western Ebro Basin; Constraints on tectonic evolution of the Sierra de Cantabria Thrust (north Spain), Proc. Int. Geol. Congr. Abstr., 32(1), 113.

Alonso, J. L., and A. Teixell (1992), Forelimb deformation in some natural examples of fault propagation folds, in Thrust Tectonics, edited by K. R. McClay, pp. 175-180, Chapman and Hall, London, U.K.

Bailey, R. C., and H. Halls (1978), The method of converging remagnetization circles; extension to include stable endpoints and error analysis, Eos Trans. $A G U, 59(12), 1037$.

Barberá, X. (1999), Magnetoestratigrafia de l'Oligocé del sector sud-oriental de la conca de l'Ebre: Implicacions magnetocronologiques i secuencials, Ph.D. thesis, 247 pp., Univ. de Barcelona, Barcelona, Spain.

Barnolas, A., and A. Teixell (1994), Platform sedimentation and collapse in a carbonate-dominated margin of a foreland basin (Jaca basin, Eocene, southern Pyrenees), Geology, 22, 1107-1110.

Bates, M. P. (1989), Palaeomagnetic evidence for rotations and deformation in the Nogueras Zone, central southern Pyrenees, Spain, J. Geol. Soc. London, 146, 459-476.

Beamud, E., M. Garcés, L1. Cabrera, J. A. Muñoz, and Y. Almar (2003), A new middle to late Eocene continental chronostratigraphy from NE Spain, Earth Planet. Sci. Lett., 216, 501-514.

Beamud, E., M. Garcés, J. A. Muñoz, L1. Cabrera, and Y. Almar (2004), Distribución de las rotaciones paleomagnéticas en la cuenca de Graus-Tremp durante el Terciario, Geotemas, 6(4), 283-286.

Beaumont, C., J. A. Muñoz, J. Hamilton, and P. Fullsack (2000), Factors controlling the Alpine evolution of the central Pyrenees inferred from a compratison of observations and geodynamical models, J. Geophys. Res., 105, 8121-8145.

Bouma, A. H. (1964), Ancient and recent turbidites, Geol. Minjbouw, 43(8), 375-379.

Cande, S. C., and D. V. Kent (1995), Revised calibration of the geomagnetic polarity timescale for the Late Cretaceous and Cenozoic, J. Geophys. Res., $100,6093-6096$.
Canudo, J. J., and E. Molina (1988), Biocronología con foraminíferos planctónicos de la secuencia deposicional de Jaca (Pirineo aragonés): Eoceno medio y superior, paper presented at II Congresso Geología de España, Inst. Geol. y Minero de España, Granada, Spain.

Casas, A. M., B. Oliva, T. Román-Berdiel, and E. L. Pueyo (2003), Basement deformation: Tertiary folding and fracturing of the Variscan Bielsa granite (central Pyrenees), Geodin. Acta, 16, 99-117.

Channell, J. E. T., and C. McCabe (1994), Comparison of magnetic hysteresis parameters of unremagnetized and remagnetized limestones, J. Geophys. Res., 99, 4613-4623.

Choukroune, P. (1976), Structure et évolution tectonique de la zone nord-pyrénéene: Analyse de la déformation dans une portion de la chaîne à schistosité subverticale, Mem. Soc. Geol. Fr., 127, 1-116.

Choukroune, P. (1992), Tectonic evolution of the Pyrenees, Annu. Rev. Earth Planet. Sci., 20, 143-158.

Choukroune, P., and M. Séguret (1973), Carte Structurale des Pyrénées, ELF-ERAP, Mission France, Boussens, France.

Choukroune, P., and ECORS Team (1990), Main results of the ECORS Pyrenees profile, Tectonophysiscs, 173, 411-423.

Day, R., M. Fuller, and V. A. Schmidt (1977), Hysteresis properties of titanomagnetites: Grain-size and compositional dependence, Phys. Earth Planet. Inter., 13, 260-267.

Dinarès, J. (1992), Paleomagnetisme a les Unitats Sudpirinenques Superiors: Implicacions estructurals, Ph.D. thesis, 462 pp., Univ. de Barcelona, Barcelona Spain.

Dinarès, J., E. McClelland, and P. Santanach (1992), Contrasting rotations within thrust sheets and kinematics of thrust tectonics as derived from palaeomagnetic data: An example from the Southern Pyrenees, in Thrust Tectonics, edited by K. R. McClay, pp. 265-276, Chapman and Hall, London.

Dinarès-Turell, J., and J. García-Senz (2000), Remagnetization of Lower Cretaceous limestones from the southern Pyrenees and relation to the Iberian plate geodynamic evolution, J. Geophys. Res., 105, $19,405-19,418$

Dunlop, D. J. (1972), Magnetic mineralogy of unheated and heated red sediments by coercivity spectrum analysis, Geophys. J. R. Astron. Soc., 27, 37-55.

ECORS Pyrenees Team (1988), The ECORS deep reflection seismic survey across the Pyrenees, Nature, $331,508-511$.
Elliot, D. (1973), Diffusion flow laws in metamorphic rocks, Bull. Geol. Soc. Am., 84, 2645-2664.

Elliot, D. (1976), The energy balance and deformation mechanisms of thrust sheets, Philos. Trans. R. Soc., 283, 289-312.

Elmore, R. D., J. Kelley, M. Evans, and T. Lewchuk (2001), Remagnetization and orogenic fluids: Testing the hypothesis in the central Appalachians, Geophys. J. Int., 144, 568-576.

Evans, M. A., and R. D. Elmore (2006), Fluid control of localized mineral domains in limestone pressure solution structures, J. Struct. Geol., 28, 284-301.

Fernández, O. (2004), Reconstruction of geological structures in 3D: An example from the southern Pyrenees, Ph.D. thesis, 321 pp., Univ. de Barcelona, Barcelona, Spain.

Fernández, O., E. Beamud, J. A. Muñoz, J. Dinarès, and J. Poblet (2003), Distribución de las rotationes paleomagnéticas en los anticlinales de Boltaña y Añisclo (Pirineos centrales), paper presented at MAGIBER II, Univ. de Coimbra, Coimbra, Portugal.

Fisher, R. A. (1953), Dispersion on a sphere, Proc. R. Soc. London, Ser. A, 217, 295-305.

Fitzgerald, P. G., J. A. Muñoz, P. J. Coney, and S. L. Baldwin (1999), Asymetric exhumation across the Pyrenean Orogen: Implications for the tectonic evolution of a collisional orogen, Earth Planet. Sci. Lett., 173, 157-170.

Garcés, M., J. García-Senz, and J. A. Muñoz (2003), Timing and causes of pervasive secondary CRM in the Cotiella massif (south central Pyrenees), Geophys. Res. Abstr., 5, 09708.

Garcés, M., J. García-Senz, J. A. Muñoz, and E. Beamud (2005), Shallow and deep burial remagnetisations in the Cotiella Massif (late Cretaceous, south central Pyrenees): Insights from rock magnetic properties, Geophys. Res. Abstr., 7, 04069.

Gong, Z., M. J. Dekkers, and J. Dinarès-Turell (2005), Toward unraveling remagnetisation mechanisms in the Organyà Basin (Pyrenees, Spain), paper presented at the 10th Scientific Assembly of the IAGA, Int. Assoc. of Geomagn. and Aeron., Toulouse, France.

Grant, N. T., D. A. Banks, A. M. McCaig, and B. W. D. Yardley (1990), The chemistry, source and behaviour of fluids involved in Alpine thrusting of the central Pyrenees, J. Geophys. Res., 95, 9123-9131.

Groshong, R. H., O. A. Pfiffner, and L. R. Pringle (1984), Strain partitioning in the Helvetic thrust belt of the eastern Switzerland from the leading edge to the internal zone, J. Struc. Geol., 6, 5-18. 
Hogan, P. J. (1993), Geocrohonologic, tectonic and stratigraphic evolution of the southwest Pyrenean foreland basin, northern Spain, Ph.D. thesis, 219 pp. Univ. of South. Calif., Los Angeles.

Hogan, P. J., and D. W. Burbank (1996), Evolution of the Jaca piggyback basin and emergence of the External Sierra, southern Pyrenees, in Tertiary Basins of Spain, edited by P. F. Friend and C. J. Dabrio, pp. 153-160, Cambridge Univ. Press, New York.

Holl, J. E., and D. J. Anastasio (1995), Cleavage development within foreland fold and thrust belt, southern Pyrenees, Spain, J. Struct. Geol., 17(3), 357-369.

Housen, B., B. A. van der Pluijm, and R. Van der Voo (1993), Magnetite dissolution and neocrystallization during cleavage formation: Paleomagnetic study of the Martinsburg Formation, Lehigh Gap, Pennsylvania, J. Geophys. Res., 98, 13,799-13,813.

Jackson, M. (1990), Diagenetic sources of stable remanence in remagnetized Paleozoic cratonic carbonates: A rock magnetic study, J. Geophys. Res., $95,2753-2761$.

Juárez, M. T., W. Lowrie, M. L. Osete, and G. Meléndez (1998), Evidence of widespread Cretaceous remagnetization in the Iberian Range and its relation with the rotation of Iberia, Earth Planet. Sci. Lett., 160, $729-743$.

Katz, B., R. D. Elmore, M. Cognoini, and S. Ferry (1998), Widespread chemical remagntetization: Orogenic fluids or burial diagenesis of clays?, Geology, 26(7), 603-606.

Keller, P., W. Lowrie, and A. U. Gehring (1994), Palaeomagnetic evidence for post-thrusting tectonic rotation in the southeast Pyrenees, Spain, Tectonophysics, 239, 29-42.

Kerrich, R., and I. Allison (1979), Flow mechanism of rocks: Microscopic and mesoscopic structures and their relation to physical conditions of deformation in the crust, Geosci. Can., 5, 109-118.

Kirschvink, J. L. (1980), The least-squares line and plane and the analysis of paleomagnetic data, Geophys. J. R. Astron. Soc., 62, 669-718.

Labaume, P., E. Mutti, M. Séguret, and J. Rossell (1983), Mégaturbidites carbonatées du bassin turbiditique de l'Eocène infèrieur et moyen sud-pyrénéen, Bull. Soc. Geol. Fr., 6, 927-941.

Labaume, P., M. Séguret, and C. Seyve (1985), Evolution of a turbiditic foreland basin an analogy with an accretionary prism: Example of the Eocene south Pyrenean basin, Tectonics, 4, 661-685.

Larrasoaña, J. C., J. M. Parés, H. Millán, J. del Valle, and E. L. Pueyo (2003a), Paleomagnetic, structural, and stratigraphic constraints on transverse fault kinematics during basin inversion: The Pamplona Fault (Pyrenees, north Spain), Tectonics, 22(6), 1071, doi:10.1029/2002TC001446.

Larrasoaña, J. C., J. M. Parés, J. del Valle, and H. Millán (2003b), Triassic paleomagnetism from the wester Pyrenees revisited: Implications for the IberianEurasia Mesozoic plate boundary, Tectonophysics, $362,161-182$

Lewchuk, M. T., M. Evans, and R. D. Elmore (2003), Synfolding remagnetization and deformation: Results from Paleozoic sedimentary rocks in West Virginia, Geophys. J. Int., 152, 266-279.

Liebermann, R. C., and S. K. Banerjee (1971), Magnetoelastic interactions in hematite: Implications for geophysics, J. Geophys. Res., 76, 2735-2756.

Lowrie, W. (1990), Identification of ferromagnetic minerals in a rock by coercivity and unblocking temperature properties, Geophys. Res. Lett., 17(2), 159-162.

Marshak, S., and E. Terry (1985), Development of cleavage in limestones of a fold-thrust belt in eastern New York, J. Struct. Geol., 7(3-4), 345-359.

Martín-Chivelet, J., X. Berástegui, E. Caus, and C. Puig (2002), Cretaceous, in Geology of Spain, edited by W. Gibbons and T. Moreno, pp. 255-292, Geol. Soc. of London, London.

Martínez-Peña, M. B., and A. M. Casas-Sainz (2003), Cretaceous-Tertiary tectonic inversion of the Cotiella Basin (southern Pyrenees, Spain), Int. J. Earth Sci., 92, 99-113.
Mattauer, M. (1976), Las Deformaciones de los Materiales de la Corteza Terrestre, 524 pp., Omega S.A., Barcelona, Spain.

Mattauer, M. (1985), Présentation d'un modèle lithosphérique de la chaîne des Pyrénées, $C$. R. Acad Sci., 300, 71-74.

Maxwell, J. C. (1962), Origin of slaty and fracture cleavage in the Delaware Water Gap area, New Jersey and Pennsylvania, in Petrologic Studies: A Volume in Honor of A.F. Buddington, edited by A. E. J. Engel, H. L. James, and B. F. Leonard, pp. 281-311, Geol. Soc. of Am., Boulder, Colo.

McCabe, C., and J. E. T. Channell (1994), Late Paleozoic remagnetization in limestones of the Craven Basin (northern England) and the rock magnetic fingerprint of remagnetized sedimentary carbonates, J. Geophys. Res., 99, 4603-4612.

McCaig, A. M., J. Tritlla, and D. A. Banks (2000), Fluid mixing and recycling during Pyrenean thrusting: Evidence from fluid inclusion halogen ratios, Geochim. Cosmochim. Acta, 64(19), 3395-3412.

McClelland, E. A., and M. McCaig (1989), Palaeomagnetic estimates of total rotation in basement thrust sheets, axial zone, southern Pyrenees, Cuad. Geol. Iberica, 12, $181-193$.

McElhinny, M. W. (1964), Statistical significance of the fold test in Paleomagnetism, Geophys. J. R. Astron. Soc., 8, 338-340.

McFadden, P. L. (1990), A new fold test for paleomagnetic studies, Geophys. J. Int., 103, 163-169.

Meigs, A. J., and D. W. Burbank (1997), Growth of the south Pyrenean orogenic wedge, Tectonics, 16 $239-258$.

Meigs, A. J., J. Vergés, and D. W. Burbank (1996), Tenmillion-year history of a thrust sheet, Geol. Soc Am. Bull., 108, 1608-1625.

Millán, H. (1996), Estructura y cinemática del frente de cabalgamiento surpirenaico en las Sierras Exteriores Aragonesas, Ph.D. thesis, 330 pp., Univ. de Zaragoza, Zaragoza, Spain

Millán, H., E. L. Pueyo, M. Aurell, A. Luzón, B. Oliva, M. B. Martínez-Peña, and A. Pocoví (2000), Actividad tectónica registrada en los depósitos terciario del frente meridional del Pirineo central, Rev. Soc. Geol. Esp., 13(2), 279-300.

Montigny, R., B. Azambre, M. Rossy, and R. Thuizat (1986), K-Ar study of Cretaceous magmatism an metamorphism in the Pyrenees: Age and length of rotation of the Iberian peninsula, Tectonophysics $129,257-273$

Muñoz, J. A. (1992), Evolution of a continental collision belt: ECORS-Pyrenees crustal balanced section, in Thrust Tectonics, edited by K. R. McClay, pp. 235-246, Chapman and Hall, London, U.K.

Muñoz, A., J. M. García-Senz, O. Fernández, and J. Dinarès-Turell (2003), 3D regional deformation patterns associated to thrust sheet rotation of the Gavarnie-Sierras Exteriores thrust sheet, Spanish Pyrenees, paper presented at AAPG Internationa Conference, Am. Assoc. of Pet. Geol., Barcelona Spain.

Mutti, E., H. Luterbacher, J. Ferrer, and J. Rosell (1972), Schema stratigrafico e lineamenti di facies del Paleogeno Marino della zona centrale sudpirenaica tra Tremp (Catalogna) e Pamplona (Navarra), Mem. Soc. Geol. Ital., 18, 15-22.

Mutti, E., R. Tinterri, G. Benevelli, D. Biase, and G. Cabaña (2003), Deltaic, mixed and turbidite sedimentation of ancient foreland basins, Mar. Pet. Geol., 20, $733-755$.

Oliva-Urcia, B. (2003), Discontinuous deformation as a mechanism of remagnetization of limestones in the Internal Sierras (southern Pyrenees, Spain), IRM $Q$. $13(1), 2-3$

Oliva-Urcia, B., and E. Pueyo (2005), Gradient of shortening and vertical axis rotations in the south western Pyrenees (Spain), Geol. Soc. Am. Abstr Programs, 37, 7.

Özdemir, O., and D. J. Dunlop (2000), Intermediate magnetite formation during dehydration of goethite, Earth Planet. Sci. Lett., 177, 59-67.
Parry, L. G. (1982), Magnetization of inmobilized particle dispersions with two distinct particle sizes, Phys. Earth Planet. Inter., 28, 230-241.

Pascual, O. (1992), Magnetoestratigrafía del estratotipo y paraestratotipo del Ilerdiense, seciones de Tremp y Campo (Cuenca de Tremp-Graus), Ph.D. thesis, Univ. Autòn. de Barcelona, Barcelona, Spain.

Payros, A., V. Pujate, and X. Orue-Etxebarria (1999), The south Pyrenean Eocene carbonate megabreccias revisited: New interpretation based on evidence from Pamplona Basin, Sediment. Geol., 125, 165 194

Payros, A., X. Orue-Etxebarria, and V. Pujate (2006), Covarying sedimentary and biotic fluctuations in lower-middle Eocene Pyrenean deep-sea deposits: Paleoenvironmental implications, Palaeogeogr. $\mathrm{Pa}$ laeoclimatol. Palaeoecol., 234, 258-276, doi:10.1016/j.palaeo.2005.10.013.

Price, N. J., and J. W. Cosgrove (1990), Analysis of Geological Structures, 502 pp., Cambridge Univ. Press, Cambridge, U. K.

Pueyo, E. L. (2000), Rotaciones paleomagnéticas en sistemas de pliegues y cabalgamientos. Tipos, causas, significado y aplicaciones (ejemplos del Pirineo Aragonés), tesis doctoral, 296 pp., Univ. de Zaragoza, Zaragoza, Spain.

Pueyo, E. L., H. Millán, and A. Pocoví (2002), Rotation velocity of a thrust: A paleomagnetic study in the External Sierras (southern Pyrenees), Sediment. Geol., 146, 191-208.

Pueyo, E. L., J. M. Parés, H. Millán, and A. Pocoví (2003a), Conical folds and apparent rotations in paleomagnetism (a case studied in the southern Pyrenees), Tectonophysics, 362, 345-366.

Pueyo, E. L., A. Pocoví, J. M. Parés, H. Millán, and J. C. Larrasoaña (2003b), Thrust ramp geometry and spurious rotations of paleomagnetic vectors, Stud. Geophys. Geod., 47, 331-357.

Pueyo, E. L., A. Pocoví, H. Millán, and A. Sussman (2004), Map-view models for correcting and calculating shortening estimates in rotated thrust fronts using paleomagnetic data, in Orogenic Curvature: Integrating Paleomagnetic and Structural Analyses, edited by A. J. Sussman and A. B. Weil, Spec. Pap. Geol. Soc. Am., 383, 57-71.

Pueyo, E. L., T. Feischl, R. Scholger, and H. J. Mauritsch (2007), Gamsstack: A program for stacking paleomagnetic data, Comput. Geosci., in press.

Pullaiah, G. E., E. Irving, K. L. Buchan, and D. J. Dunlop (1975), Magnetization changes caused by burial and uplift, Earth Planet. Sci. Lett., 21, 16241639

Ríos, L. M., J. M. Lanaja, and E. Frutos (1982a), Mapa geológico de España, scale 1:50.000, Segunda serie, Hoja 30 - 9, Broto, IGME, Serv. Publ. Min. de Ind. y Energía, Madrid.

Ríos, L. M., J. M. Lanaja, and J. M. Ríos Mitchell (1982b), Mapa geológico de España, scale 1:50.000, Segunda serie, Hoja 31 -9, Bielsa, IGME, Serv. Publ. Min. de Ind. y Energía, Madrid.

Ríos, L. M., J. M. Galera, D. Barettino, and J. M Lanaja (1987a), Mapa geológico de España, scale 1:50.000, Segunda serie, Hoja 29-8, Sallent, ITGE, Serv. Publ. Min. de Ind. y Energía, Madrid.

Ríos, L. M., J. M. Galera, and D. Barettino (1987b), Mapa geológico de España, scale 1:50.000, Segunda serie, Hoja 30-8, Bujaruelo, ITGE, Serv. Publ Min. de Ind. y Energía, Madrid.

Rochette, P., G. Fillion, J. L. Mattéi, and M. J. Dekker (1990), Magnetic transition at 30 - 34 Kelvin in pyrrhotite: Insight into a widespread occurrence of this mineral in rocks, Earth Planet. Sci. Lett., 98, 319-328.

Scheepers, P. J. J., and J. D. A. Zijderveld (1992), Stacking in paleomagnetism, application to marine sediments with weak NRM, Geophys. Res. Lett. 19(14), 1519-1522.

Schott, J. J., and A. Peres (1988), Paleomagnetism of Permo-Triassic red beds in the western Pyrenees: Evidence for strong clockwise rotations of the $\mathrm{Pa}$ leozoic units, Tectonophysics, 156, 75-88.

Séguret, M. (1972), Etude tectonique des nappes de series decollees de la partie centrale du versant 
sud des Pyrénées, Caractère synsédimentaire, rôle de la compression et de la gravité, Publ. USTELA. Ser. Geol. Struct. 2, 155 pp., Univ. des Sci. et Tech. du Languedoc, Montpellier, France.

Souquet, P. (1967), Le Crétacé supérieur sudpyrénéen en Catalogne, Aragon et Navarre, Ph.D. thesis, Univ. de Toulouse, Toulouse, France.

Storetvedt, K. M., H. Mogstad, M. C. Abranches, J. G. Mitchell, and A. Serralheiro (1987), Paleomagnetism and isotopic data from Upper Cretaceou igneous rocks of west Portugal: Geological correlation and plate tectonic aspects, Geophys. J. R Astron. Soc., 88, 241-263.

Storetvedt, K. M., J. G. Mitchell, and M. C. Abranches (1990), A new kinematic model for Iberia: Further paleomagnetic and isotopic evidence, Phys. Earth Planet. Inter., 62, 109-125.

Storti, F., F. Salvini, and K. McClay (2000), Synchronous and velocity-partitioned thrusting and thrust polarity reversal in experimentally produced, doubly-vergent thrust wedges: Implications for natural orogens, Tectonics, 19, 378-396.

Sussman, A. J., R. F. Butler, J. Dinarès-Turell, and J. Vergés (2004), Vertical axis rotation of a foreland fold and implications for orogenic curvature: An example from the southern Pyrenees, Spain, Earth Planet. Sci. Lett., 218, 435-449.

Taberner, C., J. Dinarès-Turell, J. Gimènez, and C. Docherty (1999), Basin infill architecture and evolution from magnetostratigraphic crossbasin correlations in the southeastern Pyrenean foreland basin, Geol. Soc. Am. Bull., 11, $1155-1174$

Teixell, A. (1992), Estructura alpina en la transversal de la terminación occidental de la Zona Axial pirenaica, Ph.D. thesis, 252 pp., Univ. de Barcelona, Barcelona, Spain
Teixell, A. (1996), The Ansó transect of the southern Pyrenees: Basement and cover thrust geometries, J. Geophys. Res., 102, 20,325-20,342.

Teixell, A. (1998), Crustal structure and orogenic material budget in the west central Pyrenees, Tectonics, 17, 395-406.

Teixell, A., and J. García-Sansegundo (1995), Estructura del sector central de la Cuenca de Jaca (Pirineos meridionales), Rev. Soc. Geol. Esp., 8(3), $215-228$.

Teixell, A., D. W. Durney, and M. L. Arboleya (2000), Stress and fluid control on décollement within competent limestone, J. Struct. Geol., 22, 349-371.

Travé, A., P. Labaume, F. Calvet, and A. Soler (1997), Sediment dewatering and pore fluid migration along thrust faults in a foreland basin inferred from isotopic and elemental geochemical analyses (Eocene southern Pyrenees, Spain), Tectonophysics, 282, 375-398

Vacher, P., and A. Soriau (2001), A three dimensiona model of the Pyrnean deep structure based on gravity modelling, seismic images and petrological constrains, Geophys. J. Int., 145, 460-470.

Van der Voo, R. (1969), The rotation of Spain: Paleomagnetic evidence from the Spanish Meseta, $\mathrm{Pa}$ laeogeogr. Palaeoclimatol. Palaeoecol., 3, $393-$ 416

Van der Voo, R. (1993), Paleomagnetism of the Atlantic, Tethys and Iapetus Oceans, 411 pp., Cambridge Univ. Press, New York.

Van der Voo, R., and A. Boessenkol (1973), Permian paleomagnetic results from the western Pyrenees delineating the plate boundary between the Iberian penninsula and stable Europa, J. Geophys. Res., 78, $5118-5127$.
Van der Voo, R., and J. G. Zijderveld (1971), Renewed paleomagnetic study of Iberian Penninsula, J. Geophys. Res., 76, 3913-3921.

Vergés, J., and J. García-Senz (2001), Mesozoic evolution and Cenozoic inversion of the Pyrenean rift, in PeriThetian Rift-Wrench Basins and Passive Margins, edited by W. Cavazza, A. H. F. R. Robertson, and P. A. Ziegler, pp. 187-212, Mus. Natl. d'Hist. Nat, Paris.

Vergés, J., M. Fernández, and A. Martínez (2002), The Pyrenean orogen: Pre-, syn-, and post-collisional evolution, J. Virtual Explor, 8, 57-76.

Verwey, E. J. W., and P. W. Haayman (1941), Electronic conductivity and transition point in magnetite, $P h y$ sica, 8, 979-982.

Weil, A. B., and R. Van der Voo (2002), Insights into the mechanism for orogen-related carbonate remagnetization from growth of authigenic Fe-oxide: A scanning electron microscopy and rock magnetic study of Devonian carbonates from northern Spain, J. Geophys. Res., 107(B4), 2063, doi:10.1029/ 2001JB000200.

Xu, W., R. Van der Voo, and D. R. Peacor (1998), Electron microscopic and rock magnetic study of remagnetized Leadville carbonates, central Colorado, Tectonophysics, 296, 333-362.

B. Oliva-Urcia, Departamento de Geodinamica Interna, Departamento de Ciencias de la Tierra, Universidad de Zaragoza, E-50009 Zaragoza, Spain. (boliva@unizar.es)

E. L. Pueyo, Instituto Geológico y Minero de España, Oficina De Proyectos, Manuel Lasala 44, 9C E-50009 Zaragoza, Spain. (unaim@igme.es) 